\title{
Beach market: what have we been computing in Brazil?
}

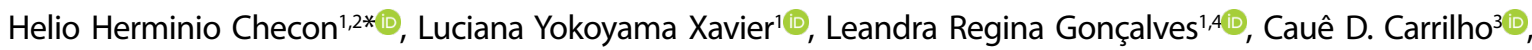 \\ Anelise Gomes da Silva ${ }^{3}$

\begin{abstract}
1 Universidade de São Paulo - Instituto Oceanográfico (Praça do Oceanográfico 191, SI. 112 - Cidade Universitária - São Paulo 05508-120 - SP - Brazil)

${ }^{2}$ Universidade Estadual de Campinas - Instituto de Biologia (Rua Monteiro Lobato 255 - Barão Geraldo - Campinas - $13083-682$ - SP - Brazil))

${ }^{3}$ Universidade de São Paulo - Instituto de Energia e Ambiente (Av. Prof. Luciano Gualberto, 1289 - Butantã - São Paulo - 05508-010 - SP - Brazil)

${ }^{4}$ Universidade Federal de São Paulo - Instituto do Mar (Rua Carvalho de Mendonça, 144 - Encruzilhada - Santos - $11070-100$ - SP - Brazil)

* Corresponding author: hchecon@yahoo.com.br
\end{abstract}

\section{Abstract}

In recent years, the identification and economic valuation of ecosystem services have been identified as an important tool to recognize and translate nature's contribution to people's well-being. It is understood that assessing the economic value of ecosystem services contributes to better decision-making process regarding ecosystems, since it helps evaluation of trade-offs in alternative scenarios. Sandy beaches are among the most valuable coastal ecosystems, especially in regards to cultural services; however, they are still commonly subjected to several impacts that compromise the ecosystem integrity and capacity to provide multiple services, especially in the Global South. For this reason, management policies are crucial to reduce negative impacts. Assessing ecosystem services should be seen as a strategic approach to provide empirical support to these policies. We reviewed studies assessing and valuing sandy beach services in Brazil to identify strengths and gaps that could guide future studies. Our analysis showed that, despite Brazil being one of the leading countries in the published literature on sandy beach science, the number of studies assessing and valuing ecosystem services are small. Most of those studies are published in the native language, Portuguese, limiting the possibility of discussion and experience exchange at the international level. The services related to the use of beaches for tourism and leisure are the main category evaluated, and studies seem to focus on tourist beaches, especially those providing monetary evaluation, which follows the global trend. An increase in the number of published studies in recent years suggests a growing interest in the research subject. Based on the literature review, we discuss the results and make recommendations to guide and foster studies assessing beach services in the context of the Ocean Science Decade.

Descriptors: Ecosystem services, Ecological economics, Global south, Coastal management, Ocean science decade.

\section{INTRODUCTION}

The degradation of the world's ecosystem is the most pressing concern of our modern society. The use and exploitation of natural resources have brought progress that came with a price; ongoing resource

Submitted: 06-April-2021

Approved: 24-November-2021

Editor: Rubens M. Lopes depletion, desertification, water and soil pollution, deforestation and climate change damage the whole planetary system and, consequently, impact human societies' welfare. The perception of such impacts has led to an increase in the recognition that conservation efforts are necessary to mitigate their effects and lessen the speed at which these processes are advancing (Carpenter et al., 2006; Armsworth et al., 2007). Carrying out such a task requires acknowledging the integration and mutual effects between social and natural subsystems of 
integrated social-ecological systems (Ban et al., 2013; Scarano, 2017).

There is an increasing body of management practices that apply the ecosystem services (ES) concept to support management and conservation practices (Daily and Matson, 2008; Fisher et al., 2008; Pascual et al., 2017). Although there is no single working definition (see Potschin \& Haines-Young, 2016; Costanza et al. 2017, for discussion), ES aims to translate the sense that natural systems provide irreplaceable benefits to human populations. According to the Millennium Ecosystem Assessment classification (MEA, 2005), that we adopt in this study, ES can be differentiated among (i) provisioning (i.e., products extracted from ecosystems); (ii) regulating (i.e., benefits generated by regulatory processes); (iii) cultural (non-material benefits generated from ecosystems); and (iv) supporting (i.e., ecosystem functions that maintain all other categories) (MEA, 2005). The use of the ES concept itself is a matter of contention among researchers. Critics state that it represents an anthropocentric and instrumentalist view of nature, whereas praisers argue that the concept includes ethical questions and considers nature's intrinsic value (Schröter et al., 2014). Regardless of the criticism, numerous initiatives acknowledge the ecosystem services concept as a powerful tool to translate nature's value to decisionmaking (Arkema et al. 2015, Ruckelshaus et al., 2015).

In addition to its recognition, the valuation of ecosystem services is an important step often applied by management-driven approaches to translate nature's benefits into monetary and/or non-monetary units. Although different valuation approaches (i.e., economic, sociocultural, and ecological) are recognized, each one with its own context and relevance, economic valuation, which aims to attribute monetary value to ecosystem services, is the most common approach (Christie et al. 2012). Since most ecosystem services are public goods, they are not usually traded in markets (De Groot et al., 2002), making their economic values often invisible to the general public and thus ignored in the decision-making process (Costanza et al., 2014). Therefore, economic valuation is a tool to reveal the monetary values of ecosystem services and guide better-informed decision-making regarding land-use decisions. Knowing the economic values of ecosystem services is especially relevant when trade-offs are involved. It can clarify how much is being lost or gained in different decision-making scenarios (Costanza et al., 2017).

The perception of the complexity of studies involving environmental economic valuation is notable, in addition to criticisms and limitations. However, experts on the subject continue to explore this challenge to contribute to decision-making (Meinard and Grill, 2011). Due to this complexity and the different theoretical approaches related to environmental economic valuation, there are various methods for determining economic values for ecosystem services (Mota et al., 2010; Christie et al., 2012). The suitability of each method depends upon the service to be valued and on the analysis's goal. When ecosystem services are traded in markets (usually provision services - e.g., commercially harvested fish), the market price is the best indicator of their economic value (Christie et al., 2012). When they are not, their monetary value can be estimated both directly and indirectly (Christie et al., 2012). For instance, if you ask people how much they would be willing to pay to conserve, restore or improve an ecosystem and its services, it is a direct assessment known as 'contingent valuation.' This method is the only one that permits the assessment of ecosystems' non-use values (e.g., existence and altruistic values) (Martin-Ortega et al., 2012). Indirect valuation of the economic value of ecosystem services are estimated by observing markets of complementary and substitute goods and services (Christie et al., 2012),

Although economic valuation is important, it will probably not fully reveal all ecosystem services' contributions to human well-being, especially when ecosystems are closely associated with historical, ethical, religious, and spiritual values. Not all attributes and ecosystem dimensions are liabilities of economic valuation; therefore, the great challenge for scholars of environmental economic valuation is to balance monetary values with non-monetary values, as there are non-quantifiable requirements for these services (Andrade and Romeiro, 2009; Mota et al., 2010; Carrilho and Sinisgalli, 2019). For this reason, economic valuation should be often complemented by sociocultural and ecological valuation approaches which do not aim to establish monetary value, but rather understand the social impact or the ecological relevance of a given service. In such cases, sociocultural approaches can complement economic 
valuation by exploring ecosystem services' contributions to people using non-monetary methods (Martín-López et al., 2014), for instance, by ranking the ecosystem services based on the preferences of a particular group. Ecological approaches, in turn, are based on the assumption that ecosystem services are products generated by nature regardless of their relationship with people. Unlike economic and sociocultural valuation, which depicts peoples' preferences, ecological valuation considers ecosystems' biophysical interdependencies. One example is estimating "emergy" (Odum, 1983) values of ecosystem services by converting all forms of energy used during its production into solar energy equivalents (Andrade and Romeiro, 2009).

Despite the evident limitations and utilitarian character (i.e., focused on practical use rather than the intrinsic value), economic valuation of ecosystem services enriches a cost-benefit analysis of investing in public policies towards environmental conservation. It highlights disregarded values, providing a way to support decision-making processes and demonstrate the importance of ecosystem services for human well-being. However, the economic perspective is not enough to support decisions that involve the conservation of natural ecosystems. The non-economic values must also be considered to overcome the limitations in environmental economic valuation practices (Costanza et al., 2014). Going beyond monetary values is regarded as an essential step for integrating ecosystem services into policies, as decision-makers seem to take an interest in the monetary valued services and non-marketable services, such as cultural ones (Ruckelshaus et al., 2015). An important step in this direction is to consider the involvement of social and human scientists in the research to include different perspectives and methods (Chan et al, 2012; McKinley et al, 2020).

Sandy beaches are a curious case among marine ecosystems. Beaches occupy around a third of the unfrosted coastlines worldwide (Luijendijk et al., 2018) and are the coastal ecosystem most used by human societies (Defeo et al., 2009), primarily due to their accessibility. Despite their natural occurrence and intimate relation with human societies, they are the least studied among coastal marine ecosystems. Research aiming to evaluate beaches as an ecosystem got traction only in the 1980s (Nel et al., 2014), and few studies focused on beaches to assess ecosystem services up until 2012 (Liquete et al., 2013).

Beaches are the main tourist attraction for many countries in the Global South (Henderson and Smith, 2009; Pécot et al., 2018) and an essential part of these countries' economies. In Brazil, the situation is no different, and sandy beaches are an integral part of society and the economy. In 2018, tourism generated US\$ 152.5 billion, responsible for $8.1 \%$ of the country's gross domestic product (WTTC, 2019), and most destinations were coastal cities (MTur, 2019). Beaches also support fisheries, both as feeding and nursery grounds for juvenile fishes and docking and sailing points for boats in small-scale fisheries. Aside from the importance for the development of tourism and fisheries, beaches provide an extensive array of distinct services, including waste depuration, stabilization and protection of shorelines against coastal erosion, dampening the effect of stochastic events, nutrient cycling, and maintenance of local communities (Schlacher et al., 2008; Barbier et al., 2011; Sardà et al., 2015).

Despite the importance of sandy beaches to human societies, beaches are under increasing pressure and threat from anthropogenic activities (Schlacher et al., 2008; Defeo et al., 2009; Harris et al., 2015). With increasing (and poorly planned) coastal urbanization, beaches are at risk of disappearing due to climate change. Global assessments of beach conditions have shown that many beaches worldwide are undergoing erosion processes (Hinkel et al., 2013; Luijendijk et al., 2019) and may disappear with increasing sea-level rise (Vousdoukas et al., 2020). Although beaches can migrate landwards to avoid disappearing due to sealevel rise (Cooper et al., 2020), in many places, there is simply no space beyond the backshore (e.g., hinterlands, dunes) to allow for such a process to occur. For this reason, appropriate management of coastal areas is vital to the protection of sandy beach ecosystems against such threats.

In this sense, efforts in beach management are crucial for maintaining the benefits generated by them. Beach sustainability also contributes to the healthier and resilient ocean desired by the United Nations Decade of Ocean Science for Sustainable Development (Ocean Science Decade), further enhancing the importance of supporting management practices. Additionally, it helps to foster the 
implementation of the 2030 Agenda, especially the SDG 14 (Life underwater) (UN, 2020).

Although still in its initial phase, ocean and coastal ecosystem services' valuation is steadily increasing worldwide (Barbier, 2012). Such studies have stressed the synergies inherent to coastal habitats, which occur in the land-sea-atmosphere interface. Assessing multiple benefits of interconnected ecosystems and habitat enables society and decision-makers to have a more comprehensive understanding of their value and what is at stake when such ecosystems are suppressed. Such a perspective is expected to result in more ecologically and economically sustainable management practices (Barbier, 2012). Additionally, to embed synergies and interconnections, a holistic and integrated approach to management is also necessary to incorporate temporal and spatial scales. For this, the ecosystem-based management approach has emerged as a promising framework. The ecosystem-based management considers the intrinsic interconnectedness of a system's ecological and social components and applies a holistic, adaptive, participatory, and knowledge-based rationale to management (Long et al., 2015). This approach has increasingly been applied to marine ecosystems. It is considered an optimum alternative to deal with the multiple interests, uses, and processes related to beach management (Sardá et al., 2015), incorporating ecosystem services valuation as a common language to discuss societal choices.

In terms of beach services, most studies seem to focus on understanding the value of this ecosystem for local and national economies in regards to tourism activities, derived either from the current earnings or from losses resulting from the degradation of the coastline (Dharmaratne and Brathwaite, 1998; Gopalakrishnan et al., 2011; Pendleton et al., 2011; Castaño-Isaza et al., 2015). This tourism-related interest in beach valuation results in a bias of studies toward areas highly dependent on these activities (Torres and Hanley, 2016). The focus on the valuation of tourism-related services also hinders the comprehension of the value of other beach services, which may have even higher monetary value than tourism (Brenner et al., 2010).

To understand the actual value of an ecosystem, the range of its services must be considered and the synergy between services recognized to provide efficient support for coastal management and policies. Due to the relatively recent development of the framework, the number of studies assessing ecosystem services has seen an increasing trend in the past few years (McDonough et al., 2017; Aznár-Sanchez et al., 2019), and is likely to be further developed in the following years and applied by different discipline areas and management sectors. However, more than just recognizing the existence of a trend, it is necessary to understand the general scope and direction of studies, such as the spatial distribution, the services assessed, and the study's spatial scale. This information is essential for guiding further studies that can provide information regarding identified gaps and under-represented topics or areas.

In this paper, we review the studies that assess and value ecosystem services of sandy beaches in Brazil as a case study of the challenges and opportunities for the development of sandy beach management in the Global South. Although we recognize the heterogeneity of the Global South countries, we also acknowledge many similarities, such as the population increases in the coastal zone and the fast and often unplanned urbanization pressuring coastal areas of developing countries (Datta and Shaban, 2017). Yet, developing economies from the Global South have their economies heavily dependent on coastal tourism or their local populations relying on small-scale fisheries. A review by Torres and Hanley (2016) found that only $7.5 \%$ of studies providing an economic valuation of ecosystem services in sandy beaches were carried out in developing countries. In this sense, this perceived gap of valuation studies in beaches of developing countries may harm the elaboration of management strategies in these areas. This scenario makes discussing and summarizing the ES in beaches more relevant. Brazil is a case in point here. It has one of the longest coastlines globally and the variability of socio-economic conditions along the country's region provides a good case study of the potential different uses and importance of beaches.

\section{METHODS}

To understand the patterns of ecosystem services studies in Brazilian beaches, we carried out a literature review related to the topic. We included studies published up to 2019. A systematic search was carried out using the terms "ecosystem services," 
"ecosystem goods," and "valuation" combined with the terms "beach" and "Brazil", both in English and in Portuguese, in the Google Scholar and Scopus database (Figure 1). We included publications of different types, including reports, theses, conference proceedings, and peer-reviewed articles that explicitly evaluated services in the Brazilian beaches. The publications included in this initial analysis were then refined by reading each manuscript abstract and results to check if the goals fitted our selection criteria. In the final review stage, we only included the documents that explicitly assessed the array of ecosystem services, considering the framework established by the MEA, and/or valued a specific or multiple services provided by beaches. Studies that focused on methods, review studies and those that do not evaluate sandy beach services individually were not included. We also excluded duplicated studies, i.e., those published in different formats but based on the same dataset/information.

From the final selection of the publications, we completed a full reading of the text and classified information according to the following categories: (1) Authorship; (2) Region; (3) type and language of publication; (4) Spatial scale (number of beaches); (5) Ecosystem services identified; (6) Estimated monetary value (if available); (7) method for valuation. Authorship analysis included the number of authors in each study, authors network analysis performed with VosViewer 1.6.16 ${ }^{\oplus}$, number of publications per author, and number of institutions. The number of beaches refers to the number of sites where services were individually evaluated. Ecosystem services were classified according to MEA categories (i.e., provisioning, supporting, regulating, cultural). Cultural services were further divided into the following categories: traditional related only, tourism-related only, complete (traditional + tourismrelated). Services were also considered individually, regardless of category, to assess which ones are most commonly identified in the studies.

To verify the existence of patterns among the spatial scale of the study, the region where the study was carried out, the application of valuation methods, and the array of services identified (i.e., single or multiple MEA categories), we applied a Multiple Correspondence Analysis, which is suitable for the ordination of categorical data (Nenadic and Greenacre, 2007). As MCA standard procedures severely underestimate inertia values, we used the Burt matrix method to correct inertia values, which preserves optimal scaling, while raising the explained inertia (Nenadic and Greenacre, 2007). The squared cosine

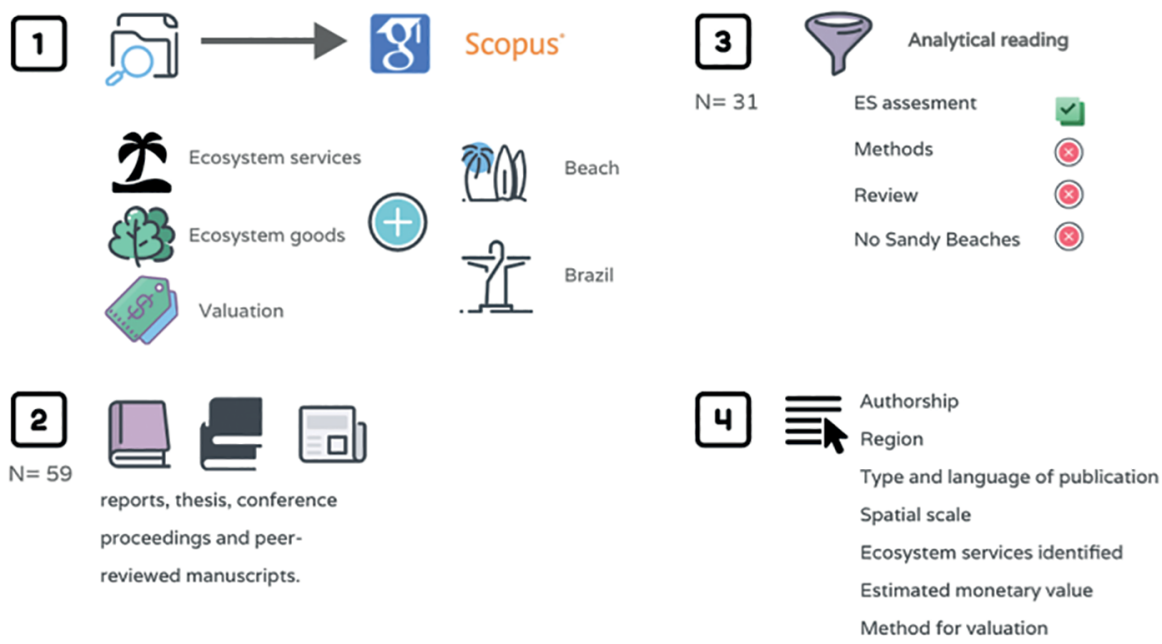

Figure 1. Descriptive illustration of the literature review methods used in this paper: (1) article search on the Scopus and Google Scholar database, based on general terms related to the review topic; (2) Initial selection of different manuscript types based on the title and abstract $(n=59)$; (3) analytical reading of the selected manuscript, excluding those dealing only with methods, reviews and those that did not assess sandy beaches $(n=31)$; (4) sorting of the information presented in the manuscript into the major categories established for the analytical review Source: Elaborated by the authors at Pitch. 
value $\left(\cos ^{2}\right)$ was estimated for the levels of each variable as a measure of the quality of the representation in the multivariate space, ranging from 0 ('poor') to 1 ('optimal'). The categorical variables were coded as follows:

(a) Spatial scale of the study: Small (1-2 beaches); Medium (3-6 beaches); Large ( $>7$ beaches)

(b) Region of the study: South (S), Southeast (SE), Northeast (NE), and North (N)

(c) Economic Valuation: Yes/No

(d) The array of services identified: Single category (usually cultural) or multiple categories.

The non-economic valuation was not included as a variable in this analysis due to the limited number of studies using this approach found in the review process.

\section{RESULTS}

After reading the abstracts that resulted from the database search, we selected 59 documents that specifically mentioned ecosystem services on beaches. After reading through the whole set, 28 that did not fit our criteria were excluded, resulting in 31 documents that we re-read to classify the information provided (Supplementary Table 1).

From the 31 documents, we identified 73 authors, but only 7 (9.5\%) appeared in more than one publication, with the maximum number of co-authorships by a single author being 4 . More than half of the publications had either a single or two authors (58\%). However, many single authorships are attributable to theses or dissertations that were not published in peer-reviewed journals. The authors' network analysis showed 25 unrelated clusters, with most clusters composed of no more than four authors, indicating little collaboration among different research groups (Figure 2). This pattern indicates a strong regionalization, with very little contribution among authors from different regions. Many clusters are composed of a single or two authors, which indicates that many of the articles represent individual efforts that may not be associated with a consolidated research group. Thirty different institutions, to which the authors are associated, were involved in the reviewed literature; 25 from Brazil and five from foreign countries (England, Wales, Canada, Portugal, and Germany). In terms of regional distribution, most studies were carried out in the northeastern region $(18,58 \%)$, followed by studies in the southern region $(7,23 \%)$, southeastern region $(5,16 \%)$, and northern region $(1,3 \%)$. From the 17 states located on the coastline of Brazil, only 6 (Amapá, Espirito Santo, Maranhão, Paraíba, Piauí and Sergipe) had no studies registered.

Most publications were from peer-reviewed scientific journals ( 21 or $68 \%$ ), with 5 (16\%) publications from conference proceedings, 4 (13\%) doctorate thesis, and a single technical report publication (3\%). The majority of these publications were published in the native Portuguese language ( 25 or $81 \%$ ), with the remaining published in English (6 or 19\%). The timeline of the number of publications shows a trend of increase since the first reviewed publications (2002). Although with oscillations in the number of publications throughout the entire period, since 2014, there is a consistent trend of at least a single publication per year (Figure 3).

Most studies were small-scale, evaluating a single $(15,48 \%)$ or two beaches $(4,13 \%)$. Ten studies assessed between 5 and 7 beaches (32\%), whereas only three studies (10\%) evaluated more than ten beaches, with the maximum number being 25 . Two studies (6\%) were of regional scope but provided no information regarding the number of evaluated beaches.

Considering MEA's four ecosystem services categories, 12 publications focused on a single category, 13 evaluated multiple categories, and six publications did not specify which services were identified. All studies that evaluated a single category focused on the identification and valuation of cultural services. Thus, cultural services were the main category of services being assessed in the published literature for Brazilian sandy beaches, with 25 publications. From these cultural services, 13 evaluated only tourism activities, 11 evaluated all cultural services, and a single study focused only on cultural services linked to traditional communities. Provisioning, regulating, and supporting services were generally identified together in the studies that focused on multiple categories, with 12,12 , and 11 publications, respectively.

A total of 45 individual services were identified on Brazilian sandy beaches (Figure 4). Most were cultural (18) and regulating (17) services. Only six supporting and four provisioning services were identified. The most commonly identified services, in order of relevance, were: Tourism activities (19), leisure/recreation (15), scenic beauty (12), food resources (e.g., fisheries, 
betkes $\mathrm{f}$ reisjv krelling ap

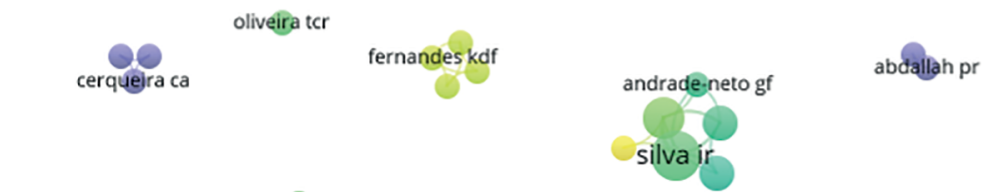

araujg rcp passos hdb uchikawa d

oliveira ktll

nascimento mal

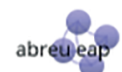

amarove

esteves, is

ferreira jcv

araujo is

bosquetti ma
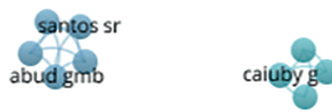

ferreira w

VOSviewer

$\operatorname{santos} d k$

paula dp

carvalho acb lins-de-barros $f$

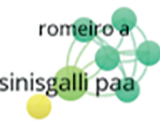

\begin{tabular}{|llllll|}
\hline & & & & \\
\hline 2008 & 2010 & 2012 & 2014 & 2016 & 2018 \\
\hline
\end{tabular}

Figure 2. Authors' network for the 31 documents from the bibliographic review. Each sphere represents a single author and the connections represent co-authored publications among them. The size of the spheres indicates the relative number of reviewed publications by a given author. For each cluster is identified the author with most connections and/or with most first authorships. Code color indicates the year of publication.

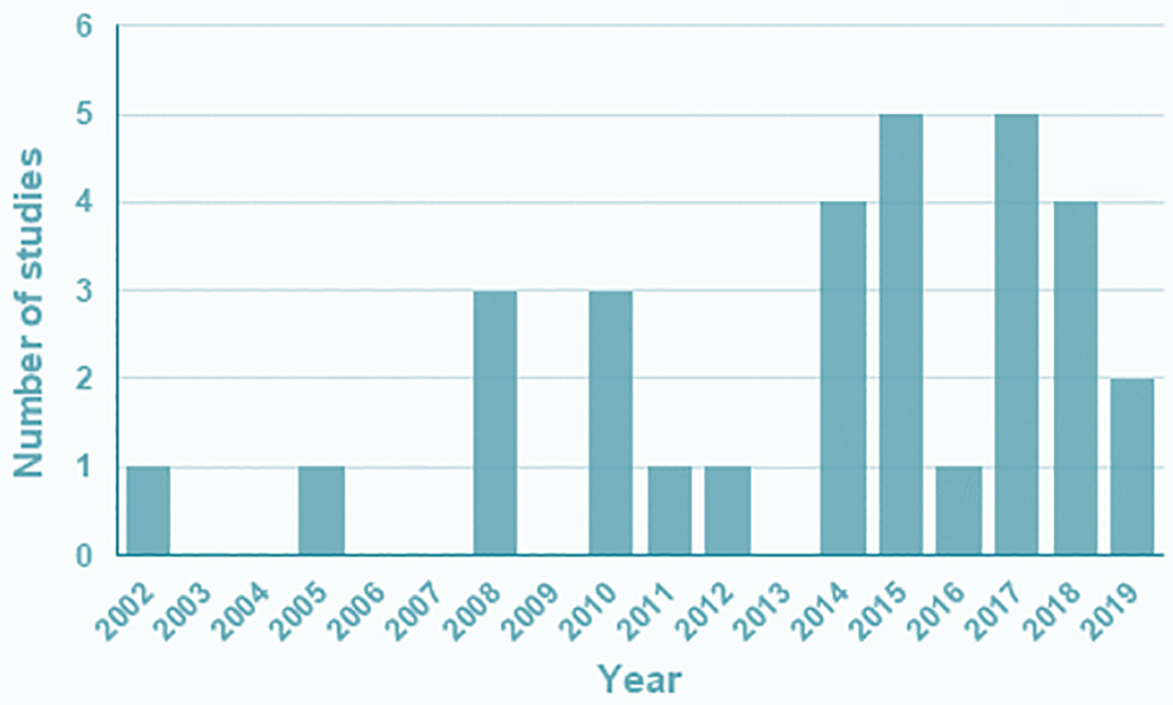

Figure 3. The number of studies assessing and/or valuing ecosystem services in Brazilian sandy beaches published per year, from 2002-2019 $(n=31)$. 


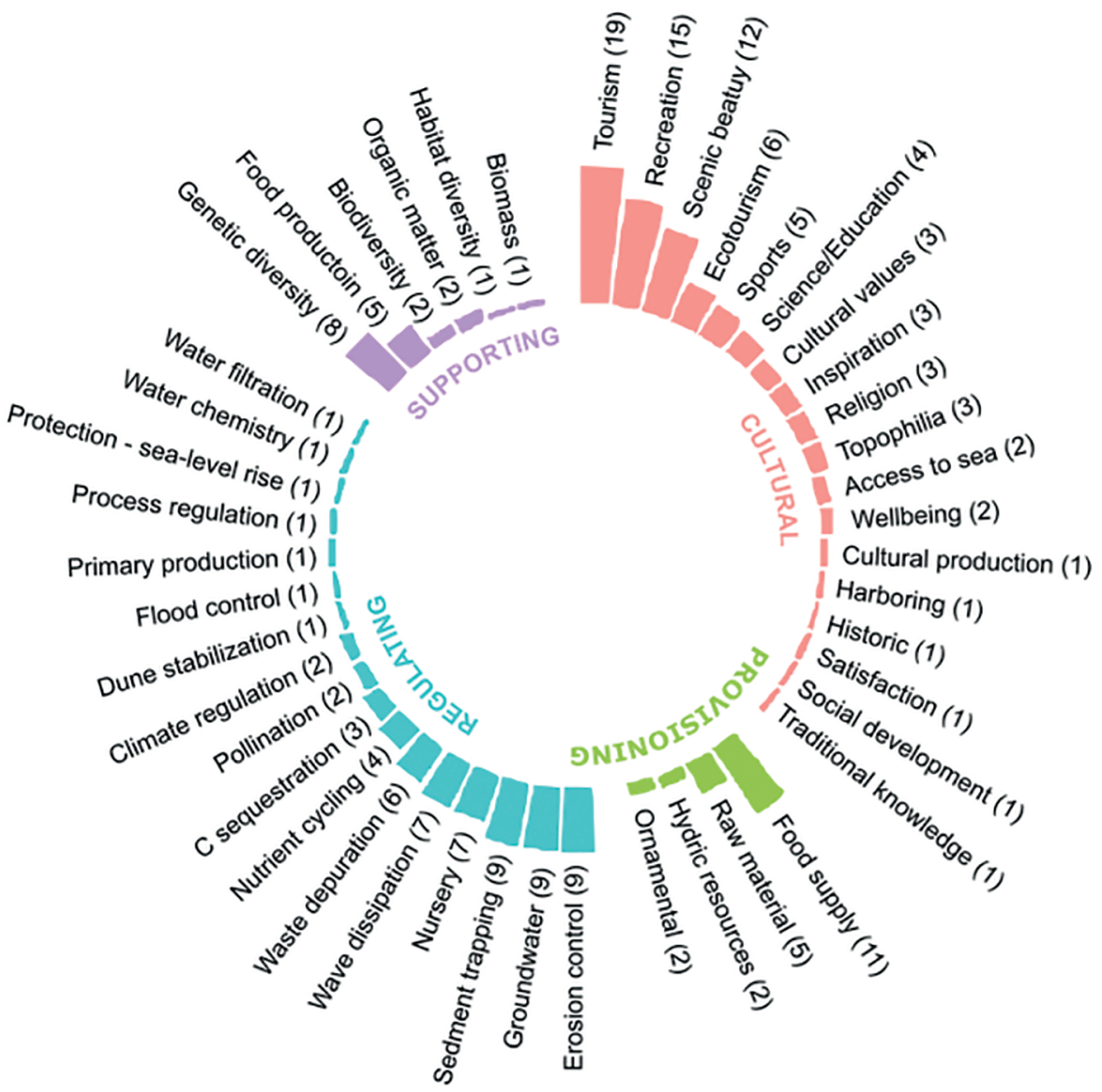

Figure 4. Ecosystem service assessed by studies in Brazilian sandy beaches. Numbers in parentheses represent the number of studies for each individual service, classified according to MEA (2005) categories.

shellfisheries) (11), groundwater retention (9), sediment trapping (9), shoreline protection/erosion control (8), genetic resources (7), nursery grounds (7), wave dissipation (6), and waste depuration (6).

From the 31 reviewed publications, 19 presented a monetary evaluation of the identified services. Most studies used valuation methods based on daily expenditure/travel cost (e.g., Bosquetti and Souza, 2009; Carvalho and Mondo, 2010; Ferreira, 2015; Krelling et al., 2017) and willingness to pay/accept (WTP/WTA) paying for a given service (e.g., Finco and Abdallah, 2002; Martins and Peres, 2005; Medeiros and Araújo, 2010; Santos-Frossard et al., 2015). Only two studies used market price and cost of replacement methods to assess the value of services (Carrilho and Sinisgalli, 2018; Linsde-Barros and Parente-Ribeiro, 2018), while two studies used non-monetary consultative methods based on questionnaires, a sociocultural valuation approach, to assess people's perception of the provision of the services (Oliveira and Berkes, 2014, Romeiro et al., 2014). Estimated values varied considerably among studies, which may reflect the differences in attractiveness, infrastructure and carrying capacity. For instance, yearly estimated value by tourism activities in a single sandy beach varied from $\mathrm{R} \$ 2,619,980,000.00 /$ year (Santos, 2017), $\mathrm{R} \$$ $7,048,928.72$ / year (Oliveira et al., 2017) to $\mathrm{R} \$ 1,750.350 /$ year (Martins and Peres, 2005). It is important to notice that tourism in itself is an economic activity, and this estimated value is not a direct estimation of beach services, but rather an indication of the underlying value of the services that support these economic activities.

The multivariate qualitative ordination shows that large-scale studies tend to assess multiple categories of services but do not apply economic valuation methods, providing just an assessment of the local beach services. On the contrary, studies providing a monetary valuation of services are usually small-scale ones. In terms of regional patterns, associations were 
lower in power (lower $\cos ^{2}$ value), but studies carried out in the Northeast were more prone to be largescale and evaluate multiple categories, which in most cases, included all categories. In contrast, studies carried out in the South were more inclined to consider a single category of services, which, as previously mentioned, are exclusive to cultural services related to tourism activities (Figure 5).

\section{DISCUSSION}

The limited knowledge of ocean processes and limits that governed our historical relationship with these complex systems is responsible for many of the impacts and injuries we face today. The Ocean Science Decade is intended to boost ocean science and increase our comprehension of the marine realm. However, fostering research is only one of the many challenges. The Ocean Science Decade proposes a new paradigm for ocean science, which advocates for more integrated, interdisciplinary, applied, innovative and participatory practices (UN, 2019). For this, using ecosystem services as a common language and their value to clarify trade-offs between management practices is a road that can take us close to future ocean sustainability.

Brazil has one of the largest coastal areas occupied by sandy beaches globally (Luijendijk et al., 2018). The extent of the beach area and its importance to the country's blue growth alone are sufficient to justify beach science investments. Indeed, Brazil is one of the leading countries in sandy beach publications (Nel et al., 2014). Considering studies on beach valuation, however, the picture is not so encouraging.

Up to 2019 , only 31 publications were identified, including articles, conference proceedings, theses, and one report; most of them published in the native language. These publications are authored by researchers disconnected from each other, representing the work of individual research groups. There is a spatial imbalance, with most studies being directed

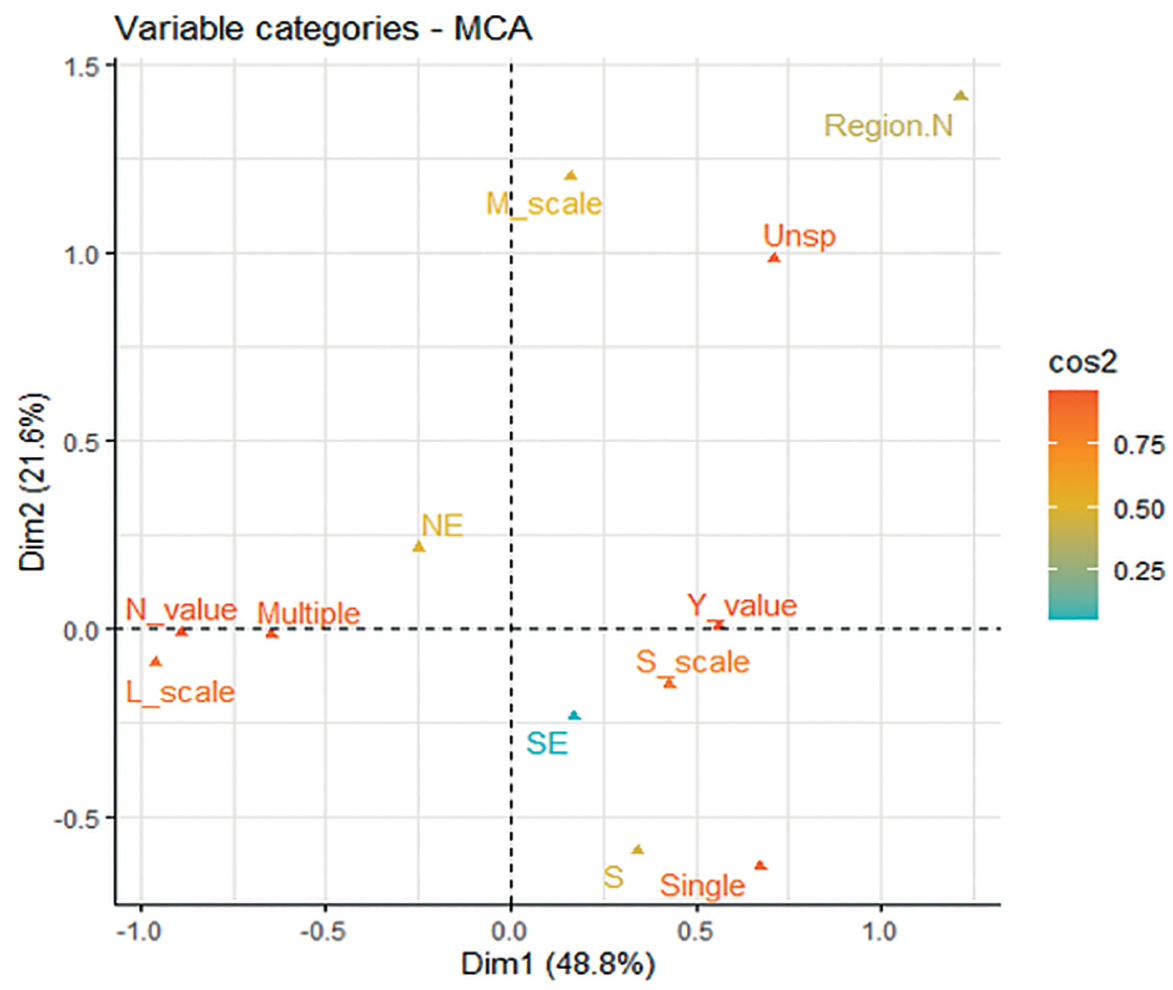

Figure 5. Multiple correspondence analysis (MCA) showing the relation among the qualitative variables of each study: (1) Spatial scale: Small scale (S_scale, 1 or 2 beaches), Medium scale (M_scale, 3-6 beaches), Large scale (L_scale, > 7 beaches); (2) Region: South (S), Southeast (SE), Northeastern (NE) and North (N); (3) Economic valuation: Yes (Y_value), No (N_value); (4) Ecosystem services categories evaluated: Single or Multiple. Distances between categories indicate their degree of similarity. The squared cosine $\left(\cos ^{2}\right)$ indicates the quality of the variable's representation in the multivariate space. 
towards the northeastern coast, which is relevant but insufficient to support a national strategy, given the distinct socio-economic conditions and varying degrees of anthropogenic pressure along the coast. Cultural ecosystem services related to the use of beaches for tourism and recreational activities are the prevailing ecosystem services category in the reviewed literature. This is understandable given the importance of beaches for tourism worldwide but limits our comprehension of other relevant services, primarily regulating ones. In particular, there is an undervaluation of fishery-related services, a critical information gap, given fisheries' relevance for developing countries' local economies (Béné et al., 2010; Hanh and Boonstra, 2018). Finally, there is a need for studies to consider a more extensive scale in evaluation. The provision of ecosystem services by beaches is directly affected by either environmental or anthropogenic conditions at multiple levels. A trans-scalar evaluation of multiple beaches and the processes that affect them can give a more comprehensive understanding of the development of beach management strategies that target ecosystem services' longterm maintenance.

On a positive note, our review indicates an increase in beach valuation studies, following an international pattern (Torres and Hanley, 2016). This increase may improve the understanding of ecosystem services in Brazilian beaches and support sustainable beach governance practices. However, the paradigm change in ocean science has to be applied to this scientific agenda's development. If the increase in beach valuation studies follows the previous trend, focusing on specific regions and ecosystem services, our progress will be limited. In other words, it is necessary to expand beach valuation science in scope and address the current issues. It is essential to look beyond the most prominent services (such as those related to tourism development) and clarify the value of other indispensable albeit invisible ecosystem services that support the whole beach ecosystem. We believe that the Ocean Science Decade is an excellent opportunity for steering beach science towards more diverse and socially relevant topics, assisting in developing the science we need for the beaches we want. For this, based on our review, we provide insights on eight main issues to be addressed in future studies and management strategies focusing on ecosystem services in sandy beaches.

\section{Foster MORE AND MORE DIVERSE VALUATION STUDIES}

We identified a total of 45 individual ecosystem services assessed and valued on Brazilian beaches. The number of studies assessing beach ecosystem services in Brazil can be seen as relatively low, especially considering the large coastal area. One of the more pressing issues for the Ocean Science Decade is providing funding and support for beach science. Through the years, Brazil's science and technology budget has been systematically reduced (Tollefson, 2019; Oliveira et al., 2020), and such cuts have affected ocean science, as less than $0.5 \%$ of the gross domestic expenditure on research is devoted to ocean science. However, investments in ocean science and technology are expected to increase through the Ocean Decade as a result of international cooperation that Brazil has celebrated over the years (IOCUNESCO, 2020), and we suggest that specific quotas should be directed in increasing our knowledge and valuation of sandy beach ecosystem services.

Most studies focused on cultural services, mainly directed towards tourist and recreational activities, which are the most commonly evaluated in beach studies worldwide (Rodríguez-Revelo et al., 2018). This is understandable, given the importance of tourist beaches to the national economy and the fact that such cultural services are more prone to a market-based valuation in contrast with other non-marketable cultural services (e.g., sense of well-being, traditional and historical value, a place for religious practices), which tend to be neglected in ecosystem services assessments in general (Milcu et al., 2013), including for sandy beaches (Torres and Hanley, 2016).

Although understandable, the focus on a single ecosystem service category or service must be treated with caution. The emphasis on tourism may perpetuate a view of sandy beaches as only bare sedimentary deposits, a vision that likely delayed the recognition of beaches as complex ecosystems and thus, the scientific advancement of sandy beach science (McLachlan and Erasmus, 1983; Nel et al., 2014). To inform more effective management, beach science must move beyond this simplistic view. Management strategies based on the ecosystem services approach must consider and integrate the multiple arrays of services provided by an ecosystem, as the provision of specific services is often interactive (Bennett et al., 2009; Guerry et al., 2012). 
When management focuses on single ecosystem services, the strategies may risk impairing the provision of other relevant services. For instance, beach nourishment, which is a soft-engineering strategy that consists of the dredging of offshore sand to be dumped in the beach face, is commonly applied as a countermeasure to beach erosion and, more recently, to mitigate effects of the predicted sea-level rise (Phillips and Jones, 2006). Although this strategy is found to be effective in enhancing the tourism potential (Phillips and Jones, 2006; Alexandrakis et al., 2015), it may have damaging consequences to the biological and physical features (Speybroeck et al., 2006; Schlacher et al., 2012; Peterson et al., 2014), which in turn may affect the provision of non-cultural services, such as productivity, nutrient cycling, carbon stock, and groundwater storage. Another example of practices that have contrasting effects on service provision is beach cleaning, enhancing beaches' tourism potential, but removing an essential organic input source, causing changes to benthic assemblages and energy flow in the ecosystem (Zielinski et al., 2019).

For a better assessment of the trade-off of applying any management strategy, a more holistic comprehension of the array of services provided by target beaches must be considered. This broader view of service provision is especially important for policies applied at regional or larger scales. When multiple beaches are targeted, the ideal scenario for managers is to identify the "natural vocation" of particular sandy beaches so that they can be individually selected, classified and managed based on the services provided as either recreational, primarily for conservation, or as a mixed-use beach (McLachlan et al., 2013). However, to recognize this so-called "vocation," management strategies need to consider the different array of services and the various pressures and activities that beaches are subjected to develop appropriate policies that consider each beach's individualities.

The majority of studies that established a valuation of ecosystem services focused on the economic approach, with only two studies using a sociocultural approach. The focus on economic valuation is common, given that this approach establishes a market value that can be better understood for economic-based decision-making. However, by itself, the economic valuation may lead to problematic conclusions for management. For instance, lacking the recognition of other services, especially the non-value ones, may lead to strategies that consider highly touristic and urbanized beaches as more important and "valuable" than pristine beaches with little urbanization, which, for example, may have higher biodiversity and ecological importance for local persistence of the species pool. While certainly an important tool, the use of monetary value for ecosystem services in decision-making should be used with caution to avoid falling into what critics call the "commoditization of nature" (McCauley 2006), which may generate negative feedback for conservation. For this reason, sociocultural and ecological approaches should be targeted in further studies, which can be complementary approaches to the groundwork that is being established by economic valuation, leading to a better understanding of the value of different categories of services (Hattam et al., 2015; Villegas-Palacio et al., 2016).

In terms of non-cultural services, studies most commonly focused on regulating services, for instance, erosion control, sediment trapping, and groundwater retention and accumulation (Defeo et al., 2009, Barbier et al., 2011; Rodríguez-Revelo et al., 2018). However, most of the Brazilian studies assessing this type of service only provide an identification of the services, without economically valuing them. Carrilho and Sinisgalli (2018) estimated that waste depuration is the most valuable service provided by a tidal flat in São Paulo (SE Brazil), worth US\$ 153,585.23/year. In contrast, carbon stocking was less relevant in the area, providing a service worth US\$ 128.40/year. Medeiros and Araújo (2010) estimated the willingness-to-pay for maintenance of the beach and the service of erosion control, finding a total worth BRL 1,561,031.60/year; this value, however, was deemed insufficient for the integrity of service provision. These two studies provide important clues regarding the value of regulating services; however, there is an urgent need for more studies to understand and translate the importance of non-cultural services provided by sandy beaches to human populations.

Notably, the number of studies estimating, and more importantly, valuing the importance of beaches to fisheries is low. Although services such as food 
supply (often unspecified) and nursery grounds are recognized in a few studies (11 and 7, respectively), others such as harboring vessels and providing access to the sea are mentioned in a single study (Carrilho and Sinisgalli, 2018). This is also the only study to provide a direct monetary evaluation of fishery-related services in sandy beaches, estimating, via cost of replacement method, a value worth US\$ 118, 090.90/ year, in a tidal flat in SE Brazil. Although many studies recognize the biodiversity and importance of beaches to Brazilian fisheries (Diegues, 1999; Tubino et al., 2007; Vasconcellos et al., 2011), these are usually not carried out under the ecosystem service context and, for this reason, do not provide a valuation that can be used to support management practices. Given the importance of small-scale fisheries to the economy and subsistence of local communities across the northern and southern regions of the Brazilian coastline (Begossi, 2010; Vasconcellos et al., 2011), recognizing and valuing these services is one of the most relevant gaps that needs to be considered in further studies.

\section{DeVelop a comparable Valuation strategy}

Even within a single category and type of service (take tourism as an example), variables used to value ecosystem services in Brazilian beaches are as diverse as the beach ecosystem themselves. For instance, Toste et al. (2011) estimated that the revenue of the hotel sector around Geribá Beach (RJ) reached a total of BRL 32,555,402/year, combining high and low tourism seasons; income from tourism at the Guarda do Embaú beach (S Brazil), famous as a surfing spot, reach US\$2,978.018 during summer months (Bosquetti and Souza, 2009). Other studies based tourism value on estimated losses due to beach erosion or poor quality. Lins-de-Barros and Ribeiro (2015) estimated that sea-level rise and coastal erosion in two highly touristic beaches in Rio de Janeiro would result in a monthly loss of BRL 1.2 mi during low and BRL $4 \mathrm{mi}$ during high season. The loss of sand on Arpoador beach during a storm event resulted in a monthly loss of BRL 160,000 (Lins-deBarros and Parente-Ribeiro, 2015). Similarly, Oliveira (2015) estimated an annual loss of BRL 3,083,074,81 for residents of a neighborhood in Bahia due to local beaches' degradation. Krelling et al. (2017) estimated yearly losses from US\$ 880,000 to US\$8.5 million with increasing litter pollution on beaches of Pontal do Sul (S Brazil).

Adding to the diversity of variables, the different methods applied may hinder comparisons even when the same ones are considered. We identified four methods for economic valuation that provide widely divergent estimates. The willingness-to-pay (WTP) was the most used method. It estimates whether and how much an individual is willing to pay to protect a given ecosystem and maintain its services, which can guide managers to identify and stipulate acceptable prices for non-marketable ecosystem services (Nielsen-Pincus et al., 2017). Although controversial, this method is commonly applied in studies to value cultural ecosystem services in coastal areas (Halkos and Matsiori, 2012; Birdir et al., 2013). Value estimates with this method are widely variable in the literature and likely to arise from distinct conditions, such as the existence of personal benefits and awareness of detrimental consequences of environmental degradation (Obeng and Aguillar, 2018). For these reasons, WTP is commonly criticized for being susceptible to variability and not reflecting the actual value (Kanya et al., 2019).

Aside from the proportion of people willing to pay for the maintenance of services provision, the WTP also depends on the value imposed or suggested to be paid for this benefit. For this reason, willingness to pay also has a temporal and political component, being heavily influenced by momentaneous situations and the general satisfaction with public policies and the current government (Matthews et al., 2017). For instance, in beaches of Ceará (NE Brazil), Leite et al. (2019) found that the unwillingness to pay was directly linked to the idea that the government should be held accountable for the conservation of beaches.

Despite the controversy, this method's use in beach studies is expected, given the prevalence of cultural services attributed to this ecosystem. Although monetary values can be estimated for some cultural services by alternative methods, contingent valuation is the only method capable of valuing services related to non-use goods, such as the ones involving spiritual and traditional values. In this sense, the WTP method provides a framework that allows people to attribute a value to specific or general activities or benefits provided by the ecosystem, allowing the valuation of non-use services (Christie et al., 2012). 
Nonetheless, studies valuing sandy beaches via the WTP method should be aware of contextual and temporal components on ecosystem services valuation to better inform management strategies.

The second most used valuation technique was the travel-cost method, which is commonly used to assess the value of touristic and recreational services (Clawson \& Knetsch 1966; Christie et al., 2012) not only in studies developed in Brazilian beaches (Abreu, 2008; Carvalho and Mondo, 2010; Krelling et al., 2017; Santos, 2017) but also worldwide (e.g., Bin et al., 2005; Ariza et al., 2012; Zhang et al., 2015). This method, by assessing the costs involved in the travel to a particular site, can be seen as a proxy of the implicit price paid by visitors to benefit from the tourism service. Albeit an appropriate method to estimate non-market services, it does suffer from some degree of uncertainty and may be biased or confounded by variables such as duration of the trip, multiple-purposes travels, or visits to multiple sites (Leh et al. 2018). Assuming a relationship between people and the service, this method cannot be used to estimate non-use values (Christie et al., 2012).

Although diversity is a positive thing and many methods are complementary, it can also preclude comparisons and hamper a nationally coordinated strategy. It is clear that the value of a beach is context-dependent, and strict comparisons bring little information. It is our understanding that having a comparable set of methods and key variables to be measured would benefit policy-making. The unavailability of a comparable strategy even impairs making sense out of data from the same beach, limiting, as an example, long-term monitoring through different studies. A sound system for valuing beaches should include multiple methods (e.g., both contingent and market price-based methods, as well as sociocultural and ecological valuation methods), which is a robust approach. We suggest that the UN's Sustainable Development Goals (SDG) should be considered to select a set of variables. For instance, when valuing tourism-related ecosystem services, it would be relevant to understand how such services are appreciated for local traditional communities beyond local enterprises such as hotels and restaurants. This information can be important for orienting public policies targeted to these communities. For instance, coastal tourism and the income from fisheries activities in Brazil were deeply affected by the 2019 oil spill (Araújo et al. 2020), and now, due to the global COVID-19 pandemic. The information regarding the value of beaches to these communities is essential to understand the extent of the impacts of tourism decrease on the local populations and promote financial support policies.

\section{Address regional imbalanCe}

Aside from the limited number of studies, there is a clear regional imbalance in the research's spatial distribution. Most ecosystem services assessments are carried out in Northeastern Brazilian beaches. This result was surprising because it follows an opposite trend regarding ecological studies on sandy beaches in Brazil, which is more directed towards Southeastern and Southern beaches (Amaral et al., 2016). In both cases, this imbalance is worrisome because extrapolations between regions are limited in power due to the distinct ecological and socio-economic conditions along the Brazilian coast (Amaral and Jablonski 2005). The southern and northern regions have particular degrees of economic development and coastal urbanization, which lead to different pressures and socio-political conflicts that affect management and conservation strategies (Amaral and Jablonski, 2005; Jablonski and Filet, 2008; Sartore et al., 2019).

It is worth noting that the focus on tourism and recreation services, valued through contingent methods, the most applied combination found in the reviewed literature, is a relatively less expensive approach than would be necessary to include other ecosystem services. For instance, to develop a trophic model, quantify carbon stock and nutrient cycling, or assess the genetic diversity, scientists rely on periodic sampling and/or analysis with specific equipment that increases the costs of research projects. Expanding the array of ecosystem services valued on beaches will, ultimately, increase regional disparities related to funding opportunities, which already have a natural unbalance due to the distinct financial development of the coastal regions (MCTI, 2020). Addressing the regional imbalance would require increased financial research support to level out regional disparities. Financial support needs to focus on human resource attraction and development, to train personnel to work with beach valuation in all regions; 
to support references centers that can facilitate and promote science and technology development; to provide needed infrastructure and equipment; and to provide funding for long-term and broader projects on beaches and coastal ecosystems in general.

\section{Foster MULTIPLE-LEVEL STUdies}

One of the reviewed studies' main characteristics is that they tend to focus on no more than two beaches, with a robust local component (lower spatial scale levels). This is a reflection of the study of ecosystem services being directed mainly towards beaches with value for tourism. Many publications are part of conference proceedings, which usually comprehend small-scale studies, further contributing to this finding. On a positive note, these studies were more likely to give a monetary valuation of beach services. This is in itself a strength of those small-scale assessments: the ability to focus on beaches of particular interest and direct more effort in valuing specific services that can aid management needs and support particular management strategies. These assessments are of great importance in particular cases. For instance, Carrilho and Sinisgalli (2018) evaluated services at Araçá Bay, a tidal flat located on Brazil's southeastern coast with multiple ecosystems, including beaches, that are threatened by the expansion of a nearby port. Identifying local ecosystem services and their valuation helped both the local community and the Public Prosecutor Office counteract the expansion project and discuss gaps and inconsistencies in environmental impact assessment (Santos and Turra, 2017; Turra et al., 2017).

There is a downside, however, for the focus on small-scale studies. Beaches are environments where the provision of ecosystem services may vary according to physical characteristics. For instance, the nursery ground provision is more relevant in embayed, low-hydrodynamic beaches (Vasconcellos et al., 2007; Oliveira and Pessanha, 2014). The morphoand hydrodynamic conditions also affect biological variables (e.g., diversity, species turnover) (Defeo and McLachlan, 2005), and services related to biodiversity (e.g., maintenance of genetic diversity, fishery resources) are likely to vary from steep-sloped, coarse-grained reflective beaches to gentle-sloped, fine-grained dissipative beaches. Socio-ecological characteristics also affect the provision of services, especially cultural ones. Beach users tend to value safe and clean beaches (i.e., lack of litter, wrack) with easy access and the presence of relevant facilities, such as kiosks (Phillips and House, 2009; Botero et al., 2013). Domestic tourists seem to favor characteristics such as the beach face's total length, whereas international tourists are prone to value more the cultural aspect of beaches (Onofri and Nunes, 2013).

For this reason, more comprehensive approaches are needed. The focus on urbanized beaches limits the understanding of the services provided by pristine or less disturbed beaches. Souza-Filho et al. (2014) found that urbanization affects services such as coastline protection and food provision on Bahia's beaches (NE Brazil). Proximity to adjacent coastal ecosystems, such as mangroves and estuaries, were also factors that affected services such as water filtration and nutrient cycling by sandy beaches (Souza-Filho et al. 2014). These factors show the importance of multilevel studies carried out on numerous sandy beaches, and that also consider neighboring ecosystems.

In Brazil, with most of the population occupying cities close to or within the coastal plain (IBGE 2010), the increasing urbanization puts intense pressure on beaches. This trend is similarly found in other Global South areas, where growing urbanization is a pressing concern (Datta and Shaban, 2017). In this sense, understanding the impacts of urbanization in the provision of services is relevant to assess what is being lost due to the degradation of the ecosystem. The presence of adjacent ecosystems is also relevant, especially given that the most extensive mangrove areas are found in the global south, in countries where beaches are also economically significant, such as Indonesia, Malaysia, Brazil, and Mexico (Feller et al., 2017). These examples of distinct environmental conditions and human pressures show that further studies should understand how these variables can affect the provision of ecosystem services by sandy beaches, which can be better achieved by comparing services provision in multiple beaches, encompassing a gradient of variability in these attributes.

\section{Promote INTER- AND TRANSDISCIPLINARITY}

Our results showed that the authors' network for the studies identified is fragmented, indicating little cooperation between research groups, each group focusing on one ecosystem service category. One 
way to expand how we study ecosystem services is through interdisciplinary efforts, where different groups of researchers could cooperate and integrate their knowledge fields. As mentioned before, Brazil was one of the leading countries in beach science publications up to 2013 ( $\mathrm{Nel}$ et al., 2014), but this does not represent beach valuation studies, which are more recent. Linking the incipient beach valuation studies to other beach science efforts that are more developed can speed up Brazil's valuation field. We noticed three significant knowledge areas in the publications: marine science, geography, and economics. Thus, interdisciplinary cooperation among economists, natural, and socio-political sciences is crucial to promote an integrated and holistic approach to management, considering beaches as social-ecological systems and fostering participatory practices that enhance social acceptance of valuation in decision-making (Torres and Hanley, 2017).

Valuation of ecosystem services is intended to support decision-making. However, there is a mismatch among the growing beach valuation literature and its application to management activities (Torres and Hanley, 2017). To close this science-policy gap, fostering more participatory practices and including politicians, decision-makers, and the general public in valuation studies is essential. Given the central role of the social context of ecosystem services value, the valuation field benefits from transdisciplinarity and makes room for it to thrive. Promoting transdisciplinarity implies integrating different social actors from different cultures, principles, and social practices (Xavier and Gonçalves, 2020) and demands new ways of producing and translating knowledge to support public policies. So far, in the analyzed publications, none of them sought to co-produce with social actors, and few brought approaches or results aiming to share principles to produce knowledge more integrated with social processes and decision making. Building knowledge with other social actors or translating the ability to contribute to the social transformation is at the core of the Ocean Science Decade and developed under the ocean literacy approach (Claudet et al., 2020).

One of the central challenges to inter and transdisciplinarity is finding a common language among practitioners. In this context, one extra advantage in working with the ecosystem services concept is that it can be used as a communication tool (Granek et al., 2010; Sardá et al., 2015). The ecosystem services concept integrates environmental attributes, social ideas, and their interrelations. Their valuation includes concepts such as the sense of belonging, perception, power, interest, values, and legitimacy in decision-making processes (Hicks et al., 2015) and gives evidence to the trade-offs of management alternatives and their consequences for the socio-ecological system (Granek et al., 2010), supporting and qualifying transdisciplinarity practices.

\section{Contribute to national and international DISCUSSIONS}

Brazil's biodiversity science output is comparable to that of developed nations (Scarano, 2007), and the country is among the leaders in sandy beach studies, being responsible for $8 \%$ of the total of studies in this ecosystem ( $\mathrm{Nel}$ et al., 2014). This highlights the importance of studies developed on Brazilian beaches to understand sandy beach ecology and dynamics. This also shows that there are consolidated research groups with a focus on this ecosystem. Despite this potential, the number of studies assessing and valuing ecosystem services is relatively low. Besides this relatively limited number, studies estimating and valuing services on Brazilian beaches are limited in international reach. Nearly $30 \%$ are published in the so-called "grey literature" (i.e., theses, conference proceedings, reports). We opted to include this type of unpublished research as it is relevant for local interest and can provide complementary information to those found in peer-reviewed articles (Saenz-Arroyo et al., 2005; Adams et al., 2017). However, it certainly has limited application for foreigners. The amount of grey literature also indicates that many Brazilian sandy beach valuation studies are not published as peerreviewed literature, which may be related to barriers such as the low accessibility of journals and little incentive to publication. Additionally, many studies are descriptive and assess small-scales, primarily of local and regional interest if the author fails to draw parallels and drive discussions of broader interests.

Most publications are in the native language, making studies more easily accessible to managers and local decision-makers. This availability can be regarded as a positive aspect, given the 
decision-making orientation of ecosystem services and valuation research. However, the prevalence of academic publications with little translation for the public may hinder scientific information in public discussions. Here again, the importance of promoting more transdisciplinary research and making the information public is stressed.

Considering the peer-reviewed articles, which represent how academics communicate among themselves, only $20 \%$ are in a non-native language, limiting the reach of the information outside the local scope. Given that sandy beaches in Brazil are exposed to similar threats, uses, and socio-economic contexts as those found elsewhere in the Global South, this number of limited-scope research studies represents a missed opportunity of an exchange of experiences and expertise that can improve the global understanding of the value and estimation of sandy beach services. This limited international scope of studies on ecosystem services on Brazilian sandy beaches is also a missed opportunity in contributing to the global development of the protection of marine ecosystems via exchange of experiences among countries, especially in the Global South, where beaches are under similar socio-economic conditions and threats.

As mentioned, 2021 marks the beginning of the Ocean Science Decade, which targets, among other goals, the use of scientific-based decisions to support strategies to improve health and foster the sustainable development of the oceans. Given the consolidated research groups in the country, coupled with the varying degrees of socio-economic conditions found along the coast, Brazil has a good potential to serve as a case study for an array of conditions that can affect marine ecosystem health and the implementations of policies for sustainable development. This is especially true considering the Global South countries, including Brazil, where many countries have their economies heavily dependent upon internal and foreign tourism, to which beaches are one of the main attractions. However, unplanned coastal development and other anthropogenic drivers may, depending on particular conditions, cause social conflicts (e.g., displacement of local communities) and fail to resolve and even exacerbate socio-economic disparities, especially when linked to the massification of luxury coastal tourism in areas with economically vulnerable populations, where jobs arising from tourism may offer precarious conditions, low income, and financial insecurity (Scheyvens and Momsen, 2015; Oviedo-García et al., 2019; Bennett et al., 2021).

The use of the ecosystem services framework has been proven to be successful in effectively guiding more sustainable management policies in coastal areas (Arkema et al., 2015, Ruckelshaus et al. 2015). However, for such a process to occur, the recognition and valuation of ecosystem services of sandy beaches need to be enhanced. Our review shows that, in one of the leading countries in sandy beach research, the use of the ecosystem services framework to identify beach value and provide support to management strategies is still limited. Aside from the low number, studies show a fragmentary nature and are primarily directed toward identifying and valuing services on tourist beaches. This indicates gaps in the understanding of beach services at the national level, given the results of previous reviews, and at the international level. This calls for a need for more studies and more integration to complete these gaps through the exchange of experiences within and between countries. Regional and international levels networks may be viable strategies to address this problem. Such initiatives are already present in the marine environment, such as the Pole-to-Pole Marine Biodiversity Observation Network of the Americas (MBON), which is a network of researchers to foster the knowledge regarding marine biodiversity and its services and of the negative impacts on the ecosystem, across the Americas, to the conservation of the ocean and coastal environments (Canonico et al. 2019). Examples such as this, coupled with the need to preserve sandy beaches, should encourage researchers to develop a network for advancing the research on ecosystem services in these ecosystems and exchange experiences on how the findings can support management strategies, primarily, but not restricted to, countries of the Global South, where the gaps in the research seem to be larger, and consider the similarities in socio-economic, ecological, and anthropogenic conditions found among developing countries worldwide.

\section{CONCLUSION}

Our study provides an overview of studies assessing and valuing sandy beach ecosystem services along the Brazilian coastline. We found that studies 
valuing beach services have been developed along the Brazilian coast, but they still are incipient given the socio-economic and ecological importance of beaches. The most noticeable gaps are the focus on the monetary evaluation of tourist and recreational use of beaches, neglecting ecological and non-use services; the evaluation of single or very few beaches; regional imbalance; and the limited number of studies published in international peer-reviewed journals. On a positive note, the number of studies is increasing, following the worldwide trend. We suggest some recommendations, based on our results, that can aid future studies and assessments to fill the gaps noted in this review. We believe that the recommendations presented here can aid further studies that can foster the development of scientific research within the Ocean Science Decade and transform the policies and governance to help the 2030 Agenda implementation in Brazil.

\section{ACKNOWLEDGEMENTS}

The authors would like to acknowledge the Fundação de Amparo à Pesquisa do Estado de São Paulo (Fapesp) for financial support (FAPESP HHC: 2018/22036-0; LYX: 2017/21797-5; LRG:2018/00462-8). The work is part of the activities of the ongoing thematic project, "Environmental Governance in the São Paulo Macrometropolis, due to climate variability" (FAPESP: 2015/03804-9), linked to the FAPESP Global Climate Change Research Program, and the project "Fostering the ecosystem-based approach in beach spatial planning and conservation," supported by FAPESP (2018/19776-2).

\section{AUTHOR CONTRIBUTIONS}

H.H.C.: Conceptualization; Formal analysis; Visualization; Writing - original draft; Writing - review \& editing;

L.Y.X.: Conceptualization; Formal analysis; Visualization; Writing - original draft; Writing - review \& editing;

L.R.G.: Conceptualization, Visualization, Writing - original draft; Writing - review \& editing; Formal analysis;

C.D.C.: Writing - original draft; Writing - review \& editing;

A.G.S.: Writing - original draft; Writing - review \& editing.

\section{REFERENCES}

ABREU, E. A. P., SILVA, A. G. \& SILVA JÚNIOR, G. G. 2008. Uma análise do custo de viagem para a Praia da Avenida em Maceió. In: XLVI Congresso SOBER (Sociedade Brasileira de Economia, Administração e Sociologia Rural). 20-23 Jul 2008, Rio Branco, Acre, Brazil. Rio Branco: SOBER, pp. 114116.
ADAMS, R. J., SMART, P. \& HUFF, A. S. 2017. Shades of grey: guidelines for working with the grey literature in systematic reviews for management and organizational studies. International Journal of Management Reviews, 19(4), 432-454.

ALEXANDRAKIS, G., MANASAKIS, C. \& KAMPANIS, N. A. 2015. Valuating the effects of beach erosion to tourism revenue: a management perspective. Ocean \& Coastal Management, 111, 1-11.

AMARAL, A. C. Z., CORTE, G. N., ROSA-FILHO, J. S., DENADAI, M. R., COLLING, L. A., BORZONE, C. A., VELOSO, V., OMENA, E. P., ZALMON, I. R., ROCHA-BARREIRA, C. A., SOUZA, J. R. B., ROSA, L. C. \& ALMEIDA, T. C. M. 2016. Brazilian sandy beaches: characteristics, ecosystem services, impacts, knowledge and priorities. Brazilian Journal of Oceanography, 64(spe2), 5-16.

AMARAL, A. C. Z. \& JABLONSKI, S. 2005. Conservation of marine and coastal biodiversity in Brazil. Conservation Biology, 19(3), 625-631.

ANDRADE, D. C. \& ROMEIRO, A. R. 2009. Serviços ecossistêmicos e sua importância para o sistema econômico e o bem-estar humano. Campinas: IE (Instituto de Economia)/UNICAMP.

ANDRÉS, M., BARRÁGAN, J. M. \& SANÁBRIA, J. G. 2017. Relationship between coastal urbanization and ecosystems in Spain. Cities, 68, 8-17.

ARAÚJO, I. S., MACIEL, A. B. C., FERREIRA, J. C. V. \& LIMA, Z. M. C. 2018. Identificação de serviços ecossistêmicos na Praia da Ponta Negra, Natal - RN. Revista de Geociências do Nordeste, 4, 298-313.

ARAÚJO, M. E., RAMALHO, C. W. R. \& MELO, P. W. 2020. Artisanal fishers, consumers and the environment: immediate consequences of the oil spill in Pernambuco, Northeast Brazil. Cadernos de Saúde Pública, 36(1), e00230319.

ARIZA, E., BALLESTER, R., RIGALL-I-TORRENT, R., SAIÒ, A., ROCA, E., VILLARES, M., JIMÉNEZ, J. A. \& SARDÁ, R. 2012. On the relationship between quality, user's perception and economic valuation in NW Mediterranean beaches. Ocean \& Coastal Management, 63, 55-66.

ARKEMA, K. K., VERUTES, G. M., WOOD, S. A., CLARKE-SAMUELS, C., ROSADO, S., CANTO, M., ROSENTHAL, A., RUCKELSHAUS, M., GUANNEL, G., TOFT, J., FARIES, J., SILVER, J. M., GRIFFIN, R. \& GUERRY, A. D. 2015. Embedding ecosystem services in coastal planning leads to better outcomes for people and nature. Proceedings of the National Academy of Sciences of the United States of America, 112(24), 7390-7395.

ARMSWORTH, P. R., CHAN, K. M. A, DAILY, G. C., EHRLICH, P. R., KREMEN, C., RICKETTS, T. H. \& SANJAVAN, M. A. 2007. Ecosystem-service science and the way forward for conservation. Conservation Biology, 21(6), 1383-1384.

AZNÁR-SANCHEZ， J. A., VELASCO-MUÑOZ， J. F., BELMONTE-UREÑA, L. J. \& MANZANO-AGUGLIARO, F. 2019. The worldwide research trends on water ecosystem services. Ecological Indicators, 99, 310-323.

BAN, N. C., MILLS, M., TAM, J., HICKS, C. C., KLAIN, S., STOECKL, N., MCKINNON, M. C., LEVINE, J., PRESSEY, R. L., SATTERFIELD, T. \& CHAN, K. M. A. 2013. A socio-ecological approach to conservation planning: embedding social considerations. Frontiers in the Ecology and the Environment, 11(4), 194-202.

BARBIER, E. B. 2012. Progress and challenges in valuing coastal and marine ecosystem services. Review of Environmental Economics and Policy, 6, 1-19. 
BARBIER, E. B., HACKER, S. D., KENNEDY, C., KOCH, E. W., STIER, A. C. \& SILLIMAN, B. R. 2011. The value of estuarine and coastal ecosystem services. Ecological Monographs, 81(2), 169-193.

BEGOSSI, A. 2010. Small-scale fisheries in Latin America: management models and challenges. MAST, 9(2), 7-31

BÉNÉ, C., HERSOUG, B. \& ALLISSON, E. H. 2010. Not by rent alone: analysing the pro-poor functions of small-scale fisheries in developing countries. Development Policy Review, 28(3), 325-358

BENNETT, N. J., BLYTHE, J., WHITE, C. S. \& CAMPERO, C. 2021. Blue growth and blue justice: ten risks and solutions for the ocean economy. Marine Policy, 125, 104387.

BIN, O., LANDRY, C. E., ELLIS, C. L. \& VOGELSONG, H. 2005. Some consumer surplus estimates for North Carolina beaches. Marine Economic Resources, 20(2), 145-161.

BIRDIR, S., UNAL, O., BIRDIR, K. \& WILLIAMS, A. T. 2013. Willingness to pay as an economic instrument for coastal tourism management: cases from Mersin, Turkey. Tourism Management, 36(C), 279-283.

BOSQUETTI, M. A. \& SOUZA, M. A. 2019. Surfonomics Guarda do Embaú, Brazil: the economic impact of surf tourism on the local economy. Florianópolis: UFSC (Universidade Federal de Santa Catarina).

BOTERO, C., ANFUSO, G., WILLIAMS, A. T., ZIELISNKI, S., SILVA C. P., CERVANTES, O., SILVA, L. \& CABRERA, J. A. 2013. Reasons for beach choice: European and Caribbean perspectives. Journal of Coastal Research, 65, 880-885

BRASIL. Ministério da Ciência, Tecnologia e Inovações. 2020. Indicadores nacionais de ciência, tecnologia e inovação - 2019. Brasília (DF): Ministério da Ciência, Tecnologia e Inovações.

BRASIL. Ministério do Turismo. 2019. Pesquisa de sondagem empresarial - Agências e organização de viagens segundo semestre 2019. Brasília (DF): Ministério do Turismo.

BRENNER, J., JIMÉNEZ, J. A., SARDÁ, R. \& GAROLA, A. 2010. An assessment of the non-market value of the ecosystem services provided by the Catalan coastal zone, Spain. Ocean and Coastal Management, 53(1), 27-38.

CANONICO, G., BUTTIGIEG, P. L., MONTES, E., MULLER-KARGER, F. E., STEPIEN, C., WRIGHT, D., BENSON, A., HELMUTH, B., CONSTELLO, M., SOUSA-PINTO, I., SAEEDI, H., NEWTON, J., APPELTANS, W., BERDNARSEK, N., BRODROSSY, L., BEST, B. D., BRANDT, A., GOODWIN, K. D., IKEN, K., MARQUES, A. C., MILOSLAVICH, P., OSTROWSKI, M., TURNER, W., ACHTERBERG, E. P., BARRY, T., DEFEO, O., BIGATTI, G., HENRY, L. A., RAMIRO-SÁNCHEZ, B., DURÁN, P., MORATO, T., ROBERTS, J. M., GARCÍA-ALEGRE, A., CUADRADO, M. S. \& MURTON, B. 2019. Global observational needs and resources for marine biodiversity. Frontiers in Marine Science, 6, 367

CARPENTER, S. R., MOONEY, H. A., AGARD, J., CAPISTRANO, D., DE FRIES, R. S., DÍAZ, S., DIETZ, T., DURAIAPPAH, A. K., OTENG-YEBOAH, A., PEREIRA, H. M., PERRINGS, C., REID, W. V., SARUKHAN, J., SCHOLES, R. J. \& WHYTE, A. V. 2009. Science for managing ecosystem services: beyond the millennium ecosystem assessment. Proceedings of the National Academy of Sciences, 106(5), 1305-1312.

CARRILHO, C. D. \& SINISGALLI, P. A. A. 2018. Contribution to Araçá Bay management: the identification and valuation of ecosystem services. Ocean \& Coastal Management, 164, 128-135.
CARVALHO, A. C. B. \& MONDO, T. S. 2010. O valor das ondas: um estudo de caso sobre a Praia do Campeche-Florianópolis na perspectiva de surfistas, moradores e visitantes. Patrimônio: Lazer e Turismo, 7(10), 75-98.

CASTAÑO-ISAZA, J., NEWBALL, R., ROACH, B. \& LAU, W.W.Y. 2015. Valuing beaches to develop payment for ecosystem services schemes in Colombia's seaflower marine protected areas. Ecosystem Services, 11(C), 22-31.

CHAN, K. M. A., SATTERFIELD, T. \& GOLDSTEIN, J. 2012. Rethinking ecosystem services to better address and navigate cultural values. Ecological Economics, 74(C), 8-18.

CHAPIN III, F. S., KOFINAS, G. P., FOLKE, C. \& CHAPIN, M. C. 2009. Principles of ecosystem stewardship: resilience-based resource management in a changing world. New York: Springer.

CHEE, Y. E. 2004. An ecological perspective on the valuation of ecosystem services. Biological Conservation, 120(4), 549565.

CHRISTIE, M., FAZEY, I., COOPER, R., HYDE, T. \& KENTER, J. O. 2012. An evaluation of the monetary and non-monetary techniques for assessing the importance of biodiversity and ecosystem services to people in countries with developing economies. Ecological Economics, 83, 67-78.

CLAUDET, J., BOPP, L., CHEUNG, W. W. L., DEVILLERS, R., ESCOBAR-BRIONES, E., HAUGAN, P., HEYMANS, J. J., MASSON-DEMOTTE, V., MATZ-LUCK, N., MILOSLAVICH, P., MULLINEAUX, L., VISBECK, M., WATSON, R., ZIVIAN, A. M., ANSORGE, I., ARAUJO, M., ARICÒ, S., BAILLY, D., BARBIÈRE, J., BARNERIAIS, C., BOWLER, C., BRUN, V., CAZENAVE, A., DIVER, C., EUZEN, A., GAYE, A. T., HILMI, N., MÉNARD, F., MOULIN, C., MUÑOZ, N. P., PARMENTIER, R., PEBAYLE, A., PÖRTNER, H. O., OSVALDINA, S., RICARD, P., SANTOS, R. S., SICRE, M. A., THIÉBAULT, S., THIELE, T., TROUBLÉ, R., TURRA, A., UKU, J. \& GAIL, F. 2020. $A$ roadmap for using the UN decade of ocean science for sustainable development in support of science, policy, and action. One Earth, 2(1), 34-42.

CLAWSON, M. \& KNETSCH, J. L. 1966. Economics of outdoor recreation. Baltimore: John Hopkins Press.

COOPER, J. A. G., MASSELINK, G., COCO, G., SHORT, A. D., CASTELLE, B., ROGERS, K., ANTHONY, E., GREEN, A. N., KELLEY, J. T. \& JACKSON, D. W. T. 2020. Sandy beaches can survive sea-level rise. Nature Climate Change, 10, 993-995.

COSTANZA, R., DE GROOT, R., BRAAT, L., KUBISZEWSKI, I., FORAMONTI, L., SUTTON, P., FARBER, S. \& GRASSO, M. 2017. Twenty years of ecosystem services: how far have we come and how far do we still need to go. Ecosystem Services, 28, 1-16.

COSTANZA, R., DE GROOT, R., SUTTON, P., VAN DER PLOEG, S., ANDERSON, S. J., KUBISZEWSKI, I., FARBER, S. \& TURNER, R. K. 2014. Changes in the global value of ecosystem services. Global Environmental Change, 26(1), 152-158.

DAILY, G. C. \& MATSON, P. A. 2008. Ecosystem services: from theory to implementation. Proceedings of the National Academy of Sciences, 105(28), 9455-9456.

DATTA, A. \& SHABAN, A. 2017. Mega-urbanization in the Global South: fast cities and new urban utopias of the postcolonial state. Abingdon: Routledge.

DEFEO, O. \& MCLACHLAN, A. 2005. Patterns, processes and regulatory mechanisms in sandy beach macrofauna: a multi-scale analysis. Marine Ecology Progress Series, 295, $1-20$. 
DEFEO, O., MCLACHLAN, A., SCHOEMAN, D. S., SCHLACHER, T. A., DUGAN, J. E., JONES, A., LASTRA, M. \& SCAPINI, F. 2009. Threats to sandy beach ecosystems: a review. Estuarine, Coastal and Shelf Science, 81(1), 1-12.

DE GROOT, R. S., MATTHEW, A. W. \& BOUMANS, R. M. J. 2002. A typology for the classification, description and valuation of ecosystem functions, goods and services. Ecological Economics, 41, 393-408.

DHARMARATNE, G. S. \& BRATHWAITE, A. E. 1998. Economic valuation of the coastline for tourism in Barbados. Journal of Travel Research, 37, 138-144.

DIEGUES, A. C. 1999. Human populations and coastal wetlands: conservation and management in Brazil. Ocean \& Coastal Management, 42(2-4), 187-210.

EPSTEIN, G., PITTMAN, J., ALEXANDER, S. M., BERDEJ, S., DYCK, T., KREITMAIR, U., RATHWELL, K. J., VILLAMAYOR-TOMAS, S., VOGT, J. \& ARMITAGE, D. 2015. Institutional fit and the sustainability of socio-ecological systems. Current Opinion in Environmental Sustainability, 14, 34-40.

FELLER, I. C., FRIESS, D. A., KRAUSS, K. W. \& LEWIS III, R. R. 2017. The state of world's mangroves in the 21 st century under climate change. Hydrobiologia, 803, 1-12.

FERREIRA, J. C. V., SILVA, E. E. S., AMARO, V. E., ESTEVES, L. S. \& FERNANDES, E. 2015. Serviços ambientais fornecidos pelas praias da Ponta Negra e Via Costeira: perspectiva de valoração. Revista do CERES, 1, 22-29.

FERREIRA, W. 2015. Os serviços ecossistêmicos e a gestão do uso público nas unidades de conservação na llha de Santa Catarina, SC. Uso Público em unidades de Conservação, 3(7), 94-102.

FINCO, M. V. A. \& ABDALLAH, P. R. 2002. Valoração econômica do meio-ambiente: o método do custo de viagem aplicado ao litoral do Rio Grande do Sul. Teoria e Evidência Econômica, $10,49-63$.

FISHER, B., TURNER, K., ZYLSTRA, M., BROUWER, R., DE GROOT, R., FARBER, S., FERRARO, P., GREEN, R., HADLEY, D., HARLOW, J., JEFFERISS, P., KIRKBY, C., MORLING, P., MOWATT, S., NAIDOO, R., PAAVOLA, J., STRASSBURG, B., YU, D. \& BALMFORD, A. 2008. Ecosystem services and economic theory: integration for policy relevant research. Ecological Applications, 18, 2050-2067.

FLANDERS MARINE INSTITUTE. 2019. Maritime Boundaries Geodatabase, version 11. Belgium: Flanders Marine Institute, DOI: https://doi.org/10.14284/382

FREIRE, C. R. F., CERQUEIRA, C. A. \& GUIMARÃES JUNIOR, G. S. 2008. Valoração econômica dos serviços ambientais como estratégia de conservação: o caso do litoral de Ilhéus-BA. In: XLVI Congresso SOBER (Sociedade Brasileira de Economia, Administração e Sociologia Rural), 20-23 Jul 2008, Rio Branco, Acre, Brazil. Rio Branco: SOBER, pp. 1-17.

GOPALAKRISHNAN, S., SMITH, M. D., SLOTT, J. M. \& MURRAY, A. B. 2017. The value of disappearing beaches: a hedonic pricing model with endogenous beach width. Journal of Environmental Economics and metrics, 61(3), 297-310.

GRANEK, E. F., POLASKY, S., KAPPEL, C. V., REED, D. J., STOMS, D. M., KOCH, E. W., KENNEDY, C. J., REED, D. J., STOMS, D. M., KOCH, E. W., KENNEDY, C. J., CRAMER, L. A., HACKER, S. D., BARBIER, E. B., ASWANI, S., RUCKELSHAUS, M., PERILLO, G. M. E., SILLIMAN, B. R., MUTHIGA, N., BAEL, D. \& WOLANSKI, E. 2010. Ecosystem services as a common language for coastal ecosystem-based management, Conservation Biology, 24(1), 207-216.
GUERRY, A. D., RUCKELSHAUS, M. H., ARKEMA, K. K., BERNHARDT, J. R., GUANNEL, G., KIM, C., MARSIK, M., PAPENFUS, M., TOFT, J. E., VERUTES, G., WOOD, S. A., BECK, M., CHAN, F., CHAN, K. M. A., GELFENBAUM, G., GOLD, B. D., HALPERN, B. S., LABIOSA, W. B., LESTER, S, E. \& LEVIN, P. S. 2012. Modeling benefits from nature: using ecosystem services to inform coastal and marine spatial planning. International Journal of Biodiversity Science, Ecosystem Services and Management, 8(1-2), 107-121.

HALKOS, G., MATSIORI, G. \& MATSIORI, S. 2012. Determinants of willingness to pay for coastal zone quality improvement. The Journal of Socio-Economics, 41(4), 391-399.

HANH, T. T. H. \& BOONSTRA, W. J. 2018. Can income diversification resolve social-ecological traps in small-scale fisheries and aquaculture in the global south? A case study of response diversity in the Tam Giang lagoon, central Vietnam. Ecology and Society, 23(3), 16.

HARRIS, L., NEL, R., HOLNESS, S. \& SCHOEMAN, D. 2015. Quantifying cumulative threats to sandy beach ecosystems: A tool to guide ecosystem-based management beyond coastal reserves. Ocean and Coastal Management, 110, 12-24.

HATTAM, C., BÖHNKE-HENRICHS, A., BÖRGER, T., BURDON, D., HADJIMICHAEL, M., DELANEY, A., ATKINS, J. P., GARRARD, $S$. \& AUSTEN, M. C. 2015. Integrating methods for ecosystem services assessment and valuation: mixed methods or mixed messages? Ecological Economics, 120, 126-138.

HENDERSON, J. C. \& SMITH, R. A. 2009. The informal tourism economy at beach resorts: A comparison of Cha-Am and Laguna Phuket in Thailand. Tourism Recreation Research, 34(1), 13-22.

HICKS, C. C., CINNER, J. E., STOECKL, N. \& MCCLANAHAN, T. R. 2015. Linking ecosystem services and human-values theory. Conservation Biology, 29(5), 1471-1480.

HINKEL, J., NICHOLLS, R. J., TOL, R. S. J., WANG, Z. B., HAMILTON, J. M., BOOT, G., VAFEIDIS, A. T., MCFADDEN, L., GANOPOLSKI, A. \& KLEIN, R. J. T. 2013. A global analysis of erosion of sandy beaches and sea-level rise: an application of DIVA. Global and Planetary Change, 111, 150-158.

IOC (Intergovernmental Oceanographic Commission), UNESCO (UNESCO (United Nations Educational, Scientific and Cultural Organization). 2020. Global Ocean Science Report 2020 - charting capacity for ocean sustainability, executive summary [online]. Paris: UNESCO Publishing. Available at: http://www.unesco. org/open-access/terms-use- [Accessed: 15 Mar 2021].

JABLONSKI, S. \& FILET, M. 2008. Coastal management in Brazil - a political riddle. Ocean \& Coastal Management, 51(7), 536-543.

KANYA, L., SANGHERA, S., LEWIN, A. \& FOX-RUSHBY, J. 2019. The criterion validity of willingness to pay methods: a systematic review and meta-analysis of the evidence. Social Science and Medicine, 232, 238-261.

KRELLING, A. P., WILLIAMS, A. T. \& TURRA, A. 2017. Differences in perception and reaction of tourist groups to beach marine debris that can influence a loss of tourism revenue in coastal areas. Marine Policy, 85, 87-99.

LEH, F. C., MOKHTAR, F. Z., RAMELI, N. \& ISMAIL, K. 2018. Measuring recreational value using travel cost method (TCM): a number of issues and limitations. International Journal of Academic Research in Business and Social Science, 8(10), 1381-1396. 
LEITE, J. S., MORAES, C. R. F., MEDEIROS, D. H. M. \& SALAZAR, I. S. O. 2019. Avaliação da disposiçao a pagar dos frequentadores de uma praia pelos benefícios ambientais. Geotemas, 9(1), 70-86.

LIMA, J. C. \& PAULA, D. P. 2017. Serviços ecossistêmicos em litorais urbanos: o caso de Fortaleza, Ceará, Brasil. In: PEREZ-FILHO, A. \& AMORIM, R. R. (eds.). Os desafios da geografia física na fronteira do conhecimento. Campinas: IG (Instituto de Geociências)/UNICAMP.

LINS-DE-BARROS, F. M. \& PARENTE-RIBEIRO, L. 2018. How much is a beach worth: economic use and vulnerability to coastal erosion: the case of Ipanema and Arpoador beaches, Rio de Janeiro (Brazil). In: LEAL FILHO, W. \& FREITAS, L. E. (eds). Climate change adaptation in Latin America. New York: Springer, pp. 207-222.

LIQUETE, C., PIRODDI, C., DRAKOU, E. G., GURNEY, L., KATSANEVAKIS, S., CHAREF, A. \& EGOH, B. 2013. Current status and future prospects for the assessment of marine and coastal ecosystem services: a systematic review. PLoS One, 8(7), e67737.

LONG, R. D., CHARLES, A. \& STEPHENSON, R. L. 2015. Key principles of marine ecosystem-based management. Marine Policy, 57, 53-60.

LUIJENDIJK, A., HAGENAARS, G., RANASINGHE, R., BAART, F., DONCHTYS, G. \& AARNINKHOF, S. 2018. The state of the world's beaches. Scientific Reports, 8(1), 6641.

MARTÍN-LÓPEZ, B., GÓMEZ-BAGGETHUN, E., GARCÍA-LLORENTE, M. \& MONTES, C. 2014. Trade-offs across value-domains in ecosystem services assessment. Ecological Indicators, 37, 220-228.

MARTIN-ORTEGA, J., BROUWER, R., OJEA, E. \& BERBEL, J. 2012. Benefit transfer and spatial heterogeneity of preferences for water quality improvements. Journal of Environmental Management, 106, 22-29.

MARTÍNEZ, M. L., INTRALAWAN, A., VÁZQUEZ, G., PÉREZ-MAQUEO, O., SUTTON, P. \& LANDGRAVE, R. 2007. The coasts of our world: Ecological, economic and social importance. Ecological Economics, 63(2-3), 254-272.

MARTINS, E. C. \& PERES, F. C. 2005 . O turismo como alternativa de desenvolvimento sustentável: o caso de Jericoacoara, Ceará. Revista Econômica do Nordeste, 36(2), 228-241.

MATTHEWS, Y. S., SCARPA, R. \& MARSH, D. 2017. Stability of willingness-to-pay for coastal management: a choice experiment across three time periods. Ecological Economics, 138, 64-73.

MEDEIROS, E. C. S. \& ARAÚJO, R. C. P. 2010. Valoração ambiental dos serviços ambientais de controle da erosão da Praia do Icaraí, Caucaia-CE. In: $48^{\circ}$ Congresso SOBER (Sociedade Brasileira de Economia, Administração e Sociologia Rural), 25-28 Jul 2010, Campo Grande, Mato Grosso do Sul, Brazil. Campo Grande: SOBER, pp. 1-18.

MCCAULEY, D. J. 2006. Selling out on nature. Nature, 443 , 27-28.

MEINARD, Y. \& GRILL, P. 2011. The economic valuation of biodiversity as an abstract good. Ecological Economics, 70(10), 1707-14.

MCDONOUGH, K., HUTCHINSON, S., MOORE, T. \& HUTCHINSON, J. M. S. 2017. Analysis of publication trends in ecosystem services research. Ecosystem Services, 25, 82-88.
MCKINLEY, E., ACOTT, T. \& YATES, K. L. 2020. Marine social sciences: looking towards a sustainable future. Environmental Science \& Policy, 108, 85-92.

MCLACHLAN, A. \& ERASMUS, T. 1983. Sandy beach as ecosystems. New York: Springer.

MCLACHLAN, A., DEFEO, O., JARAMILLO, E. \& SHORT, A. D. 2013. Sandy beach conservation and recreation: guidelines for optimising management strategies for multi-purpose use. Ocean \& Coastal Management, 71, 256-268.

MEA (Millenium Ecosystem Asssessment). 2005. Ecosystems and human well-being: synthesis. Washington: Island Press.

MILCU, A. I., HANSPACH, J., ABSON, D. \& FISCHER, J. 2013. Cultural ecosystem services: a literature review and prospects for future research. Ecology and Society, 18(3), 44.

MOTA, J. A., BURSTZYN, M., CÂNDIDO JÚNIOR, J. O. \& ORTIZ, R. A. 2010. A valoração da biodiversidade: conceitos e concepções metodológicas. In: MAY, P. H. (ed.). Economia do meio ambiente. $4^{\text {th }}$ ed. Rio de Janeiro: Elsevier, pp. 265-287.

NEL, R., CAMPBELL, E. E., HARRIS, L., HAUSER, L., SCHOEMAN, D. S., MCLACHLAN, A., DU PREEZ, D. R., BEZUIDENHOUT, K. \& SHLACHER, T. A. 2014. The status of sandy beach science: past trends, progress and future trends. Estuarine, Coastal and Shelf Science, 150, 1-10.

NENADIC, O. \& GREENACRE, M. J. 2007. Correspondence analysis in $\mathrm{R}$, with two or three-dimensional graphics: the ca package. Journal of Statistical Software, 20, 1-13.

NIELSEN-PINCUS, M., SUSSMAN, P., BENNETT, D. E., GOSNELL, H. \& PARKER, R. 2017. The influence of place on the willingness to pay for ecosystem services. Society \& Natural Resources, 30(12), 1423-1441.

OBENG, E. A. \& AGUILLAR, F. X. 2018. Value orientation and payment for ecosystem services: perceived detrimental consequences lead to willingness-to-pay for ecosystem services. Journal of Environmental Management, 206, 458-471.

ODUM, H. T. 1983. Systems ecology: an introduction. New York: Wiley Press.

OLIVEIRA, C. R., MACHADO, G. C., GONÇALVES, R. R. \& FERNANDES, K. D. S. 2017. Castelos de lama: uma proposta de valoração ambiental na Praia do Cassino, Rio Grande do Sul, Brasil. Revista Espacios, 38, 5.

OLIVEIRA, E. A., MARTELLI JÚNIOR, H., SIMÕES E SILVA, A. C., MARTELLI, D. R. B. \& OLIVEIRA, M. C. L. 2020. Science funding crisis in Brazil and covid-19: deleterious impact on scientific output. Anais da Academia Brasileira de Ciências, 92(4), 1-3.

OLIVEIRA, K. T. L. L. 2015. Análise de valoração contingente das praias do bairro Rio Vermelho, Salvador-BA: uma aplicação dos instrumentos econométricos logit e probit. Nexos Econômicos, 9(1), 135-162.

OLIVEIRA, L. E. C. \& BERKES, F. 2014. What value São Pedro's procession? Ecosystem services from local people perception. Ecological Economics, 107, 114-121.

OLIVEIRA, R. E. M. C. C. \& PESSANHA, A. L. M. 2014. Fish assemblages along a morphodynamic continuum on three tropical beaches. Neotropical Ichthyology, 12(1), 165-175.

OLIVEIRA, T. C. R. 2015. Uso e qualidade de praias arenosas da Ilha de Santa Catarina, SC, Brasil: bases para seu planejamento ambiental. MSc. Florianópolis: UFSC (Universidade Federal de Santa Catarina). 
ONOFRI, L. \& NUNES, P. A. L. D. 2013. Beach 'lovers' and 'greens': a worldwide empirical analysis of coastal tourism. Ecological Economics, 88, 49-56.

OVIEDO-GARCÍA, M. A., GONZÁLEZ-RODRÍGUEZ, M. R. \& VEGA-VÁSQUEZ, M. 2008. Does sun-and-sea all-inclusive tourism contribute to poverty alleviation and/or income inequality reduction? The case of the Dominican Republic. Journal of Travel Research, 58(6), 995-1013.

PASCUAL, U., BALVANERA P., DÍAZ, S., PATAKI, G., ROTH, E., STENSEKE, M., WATSON, R. T., DESSANE, B. E., ISLAR, M., KELEMEN, E., MARIS, V., QUAAS, M., SUBRAMANIAN, S. M., WITTMER, H., ADLAN, A., AHN, S. Y. S., AL-HAFEDH, A. E., ASAH, S.T., BERRY, P., BILGIN, A., BRESLOW, S. J., BULLOCK, C, DANIEL, C., DALY-HASSEN, H., FIGUEROA, E., GOLDEN, C. D, GÓMEZ-BAGGETHUN, E., GONZÁLEZ-JIMÉNEZ, D., HOUDET, J., KEUNE, H., KUMAR, R., MA, K., MAY, P. H., MEAD, A., O'FARRELL, P., PANDIT, R., PENGUE, W., PICHIS-MADRUGA, R., POPA, F., PRESTON, S., PACHECO-BALANZA, D., SAARIKOSKI, H., STRASSBURG, B. B., VAN DEN BELT, M., VERMA, M., WICKSON, F. \& YAGI, N. 2017. Valuing nature's contributions to people: the IPBES approach. Current Opinion in Environmental Sustainability, 26-27, 7-16.

PAUNA, V. H., PICONE, F., LE GUYADER, G., BUONOCORE, E. \& FRANZESE, P. P. 2018. The scientific research on ecosystem services: a bibliometric analysis. Ecological Questions, 29(3), 53-62.

PÉCOT, M., GAVILANES, J. \& VITERI, A. S. 2018. Tales of informality: tourism development in four ecuadorian beaches. Tourism Planning and Development, 15(5), 584-599.

PENDLETON, L., KING, P., MOHN, C., WEBSTER, D. G., VAUGHN, R. \& ADAMS, N. P. 2011. Estimating the potential economic impacts of climate change on Southern California beaches. Climatic Change, 109, 277-298.

PETERSON, C. H., BISHOP, M. J., D'ANNA, L. M. \& JOHSON, G. A. 2014. Multi-year persistence of beach habitat degradation from nourishment using coarse shelly sediments. Science of the Total Environment, 487, 481-492.

PHILIPS, M. R. \& HOUSE, C. 2009. An evaluation of priorities for beach tourism: case studies from South Wales, UK. Tourism Management, 30(2), 176-183.

PHILIPS, M. R. \& JONES, A. L. 2006. Erosion and tourism infrastructure in the coastal zone: problems, consequence and management. Tourism Management, 27(3), 517-524.

REIS, J. V. 2018. Valoração dos serviços ambientais culturais das praias do município de Tamandaré, Litoral Sul do Estado de Pernambuco, Brasil. MSc. Recife: UFPE (Universidade Federal de Pernambuco).

RODRÍGUEZ-REVELO, N., ESPEJEL, I., GARCÍA, C. A., OJEDA-REVAH, L. \& VÁSQUEZ, M. A. S. 2018. Environmental Services of Beaches and Coastal Sand Dunes as a Tool for Their Conservation. In: BOTERO, C. M., CERVANTES, O. D. \& FINKL, C. W. (eds). Beach management tools - concepts, methodologies and case studies. New York: Springer, pp. 75-100.

ROMEIRO, A., SINISGALLI, P., JERICÓ-DAMINELLO, C., SESSIN-DILASCIO, K., LIMA, L., SCHROETER, B. \& SOBRINHO, R. P. 2014. A comunidade do parque do Marujá e o Parque Estadual da Ilha do Cardoso: co-manejo, serviços ecossistêmicos e processo socio-técnico. Revista Virtual Redesma, 7, 75-85.

RUCKELSHAUS, M., MCKENZIE, E., TALLIS, H., GUERRY, A., DAILY, G., KAREIVA, P., POLASKY, S., RICKETTS, T., BHAGABATI, N., WOOD, S. A. \& BERNHARDT, J. R. 2015. Notes from the field: lessons learned from using ecosystem services approach to inform real-world decisions. Ecological Economics, 115, 11-21.
SÁENZ-ARROYO, A., ROBERTS, C. M., TORRE, J. \& CARIÑO-OLIVEIRA, M. 2005. Using fishers' anecdotes, naturalists' observations and grey literature to reassess marine species at risk: the case of the Gulf grouper in the Gulf of California, Mexico. Fish and Fisheries, 6(2), 121-133.

SANTOS, D. K. 2017. Valor econômico do turismo em uma praia urbana. Graduate. Natal: UFRN (Universidade Federal do Rio Grande do Norte.

SANTOS, R. S., ALMEIDA, C. R., SILVA, L. F., ABUD, G. M. B. \& MATTOS, C. A. C. 2010. A disposição a pagar (DAP) e a valoração de ativos ambientais: uma aplicação do método na praia do Atalaia em Salinópolis - PA. In: XIV INIC (Encontro Latino Americano de Iniciação Científica), 21-22 Out 2020, São José dos Campos, São Paulo, Brazil. São José dos Campos: UNIVAP (Universidade do Vale do Paraíba), pp. 1-6.

SANTOS, R. \& SILVA, I. 2012. Serviços ecossistêmicos oferecidos pelas praias do município de Camaçari, Litoral Norte do Estado da Bahia, Brasil. Cadernos de Geociências, 9(1), 47-56.

SANTOS-FROSSARD, T. C., PASSOS, H. D. B., SILVA, M. S. \& SANTOS, C. S. C. 2018. Valoração ambiental da Praia da Coroinha, Itacaré/BA. Informe Gepec, 19, 90-108

SANTOS, C. R. \& TURRA, A. 2017. Rumos da sustentabilidade costeira: uma visão do litoral norte paulista. $1^{\text {st }}$ ed. São Paulo: Instituto Oceanográfico.

SARDÁ, R., VALLS, J. F., PINTÓ, J., ARIZA, E., LOZOYA, J. P., FRAGUELL, R. M., MARTÍ, C., RUCABADO, J., RAMIS, J. \& JIMENEZ, J. A. 2015. Towards a new integrated beach management system: the ecosystem-based management system for beaches. Ocean and Coastal Management, 118, 167-177.

SARTORE, M. S., PEREIRA, S. A. \& RODRIGUES, C. 2019. Aracaju beach bars as a contested market: Conflicts and overlaps between market and nature. Ocean and Coastal Management, 179, 104828

SCARANO, F. R. 2007. Perspective on biodiversity science in Brazil. Scientia Agricola, 64(4), 439-447.

SCARANO, F. R. 2017. Ecosystem-based adaptation to climate change: concept, scalability and a role for conservation science. Perspectives in Ecology and Conservation, 15(2), 6573.

SCHEYVENS, R. \& MOMSEN, J. H. 2008. Tourism and poverty reduction: issues for small island states. Tourism Geographies, 10(1), 22-41.

SCHLACHER, T. A., NORIEGA, R., JONES, A. \& DYE, T. 2012. The effects of beach nourishment on benthic invertebrates in Eastern Australia: impacts and variable recovery. Science of the Total Environment, 435, 411-417.

SCHLACHER, T. A., SCHOEMAN, D. S., DUGAN, J., LASTRA, M., JONES, A., SCAPINI, F. \& MCLACHLAN, A. 2008. Sandy beach ecosystems: key features, sampling issues, management challenges and climate change impacts. Marine Ecology, 29(Suppl 1), S70-S90.

SCHRÖTER, M., VAN DER ZENDEN, E. H., VAN OUDENHOVEN, A. P. E., REMME, R. P., SERNA-CHAVEZ, H. M., DE GROOT, R. S. \& OPDAM, P. 2014. Ecosystem services as a contested concept: a synthesis of critique and counter-arguments. Conservation Letters, 7(6), 514-523.

SILVA, A. E. S. \& PAULA, D. P. 2017. Avaliação dos serviços ecossistêmicos oferecidos pelas praias do município de Caucaia, Ceará, Brasil. In: PEREZ-FILHO, A. \& AMORIM, R. R. (orgs.). Os desafios da geografia física na fronteira do conhecimento. Campinas: IG (Instituto de Geociências). 
SILVA, I. R., ANDRADE NETO, G. F., SOUSA FILHO, J. R. \& ELIFF, C. I. 2014. Fatores naturais e antropogênicos condicionando o uso recreacional da praia de Jauá, Região Metropolitana de Salvador, Bahia. Scientia Plena, 10(6), 1-11.

SILVA, M. L. N. \& NASCIMENTO, M. A. L. 2016. Os valores da geodiversidade de acordo com os serviços ecossistêmicos sensu murray gray aplicados a estudos in situ na cidade do Natal (RN). Caderno de Geografia, 26(2), 338-354.

SOUZA, C. R. G. 2012. Praias oceânicas do Estado de São Paulo: síntese do conhecimento sobre morfodinâmica, sedimentologia, transporte costeiro e erosão costeira. Revista do Departamento de Geografia, 30, 308-317.

SOUZA-FILHO, J. R., SANTOS, R. C., SILVA, I. R. \& ELLIFF, C. I. 2014. Evaluation of recreational quality, carrying capacity and ecosystem services supplied by sandy beaches of the municipality of Camaçari, northern coast of Bahia, Brazil. Journal of Coastal Research, 70, 527-532.

SOUZA-FILHO, J. R., SILVA, I. R. \& NUNES, F. C. 2019. Avaliação qualitativa dos serviços ecossistêmicos oferecidos pelas praias da APA da Lagoa Encantada/Rio Almada, Bahia, Brasil. Caminhos de Geografia, 20(72), 15-32.

SPEYBROECK, J., BONTE, D., COURTENS, W., GHESKIERE, T., GROOTAERT, P., MAELFAIT, J. P., MATHYS, M., PROVOOST, S., SABBE, K., STIENEN, E., LANCKER, V., VINCX, M. \& DEGRAER, S. 2006. Beach nourishment: an ecologically sound coastal defence alternative? A review. Aquatic Conservation, 16, 419-435.

STROKKE, O. S. 2001. The interplay of international regimes: putting effectiveness theory to work. The Fridtjof Nansen Institute, 27.

TOLLEFSON, J. 2019. "Tropical Trump" sparks unprecedented crisis for Brazilian science. Nature, 572(7768), 161-162.

TORRES, C. \& HANLEY, N. 2016. Economic valuation of coastal and marine ecosystem services in the 21st century: an overview from a management perspective. working papers in environmental economics. Report No. 2016-1 [online]. St. Andrews: University of St. Andrews. Available at: http://www.st-andrews.ac.uk/ gsd/ research/envecon/eediscus/ [Accessed: 20 March 2020].

TORRES, C. \& HANLEY, N. 2017. Communicating research on the economic valuation of coastal and marine ecosystem services. Marine Policy, 75, 99-107.

TOSTE, R., CAIUBY, G., FREITAS, M. \& RIBEIRO, N. 2011. Vulnerabilidade costeira às mudanças climáticas Armação de Búzios (RJ, Brasil). In: XIV IWRA (World Water Congress), 25-29 Set 2011, Porto de Galinhas, Pernambuco, Brazil. Porto de Galinhas: IWRA, pp. 11-13.

TUBINO, R. A., MONTEIRO-NETO, C., MORAES, L. E. S. \& PAES, E. T. 2007. Artisanal fisheries production in the coastal zone of Itaipu, Nitéroi, R, Brazil. Brazilian Journal of Oceanography, 55(3), 187-197.
TURRA, A., AMARAL, A. C. Z., CIOTTI, A. M., ROSSI-WONGTSCHOWSKI, C. L. D. B., SCHAEFFER-NOVELLI, Y., MARQUES, A. C., SIEGLE, E., SINISGALLI, P. A., SANTOS, C. R. \& CARMO, A. B. 2017. Environmental impact assessment under an ecosystem approach: the São Sebastião Harbor Expansion Project. Ambiente \& Sociedade, 20(3), 155-176.

UCHIKAWA, D. 2008. Verificando a importância ambiental da praia de Boa Viagem utilizando métodos de valoração ambiental. MSc. Recife: UFPE (Universidade Federal de Pernambuco).

UN (UNITED NATIONS). 2014. Blue economy concept paper [online]. San Francisco: UN. Available at: https://sustainabledevelopment.un.org/content/documents/2978BEconcept. pdf [Accessed: 20 Dec 2021].

UN (UNITED NATIONS). IOC (Intergovernmental Oceanographic Commission). 2019. The science we need for the ocean we want: the United Nations decade of ocean science for sustainable development (2021-2030). Paris: IOC Publishing.

VASCONCELLOS, M., DIEGUES, A. C. \& KALIKOSKI, D. C. 2011 Coastal fisheries of Brazil. In: SALAS, R., CHEUNPAGDEE, A. CHARLES, A. \& SEIJO, J. A. (eds). Coastal fisheries of Latin America and the Caribbean. Rome: FAO Fisheries and Aquaculture Technical Paper, pp. 73-116.

VASCONCELLOS, R. M., SANTOS, J. N. S., SILVA, M. A. \& ARAÚJO, F. G. 2007. Efeito do grau de exposição às ondas sobre a comunidade de peixes juvenis em praias arenosas do município do Rio de Janeiro, Brazil. Biota Neotropica, 7(1), 93-100.

VILLEGAS-PALACIO, C., BERROUET, L., LÓPEZ, C., RUIZ, A. \& UPEGUI, A. 2016. Lessons from the integrated valuation of ecosystem services in a developing country: three case studies on ecological, socio-cultural and economic valuation. Ecosystem Services, 22, 297-308.

VOUSDOUKAS, M. I., RANASINGHE, R., MENTASCHI, L., PLOMARITIS, T. A., ATHANASIOU, P., LUIJENDIJK, A. \& FEYEN, L. 2020. Sandy coastlines under threat of erosion. Nature Climate Change, 10(3), 260-263.

WTTC (World Travel and Tourism Council). 2019. Travel and tourism economic impact 2019 [online]. London: WTTC. Available at: https://wttc.org/Research/Economic-Impact [Accessed: 20 March 2020].

ZHANG, F., WANG, Z. H., NUNES, P. A. L. D. \& MA, C. 2015. The recreational value of gold coast beaches, Australia: an application of the travel cost method. Ecosystem Services, 11, 106-114.

ZIELINSKI, S., BOTERO, C. M. \& YANES, A. 2019. To clean or not to clean? A critical review of beach cleaning methods and impacts. Marine Pollution Bulletin, 139, 390-401. 